\title{
Yıkıcı yönetim, sanal kaytarma ve işteki üretkenlik: Banka çalışanları üzerine bir araştırma ${ }^{1}$
}

\author{
Abusive supervision, cyberloafing, and productivity at work: A study \\ on bank employees
}

\author{
Seda Güğerçin² \\ Mustafa Fedai Çavuş ${ }^{3}$
}

1 Bu çalışma, 2020 yılında tamamlanan, "Sanal Kaytarma Davranışı ve Yıkıcı Yönetim Algisının İşteki Üretkenlik Üzerine Etkisi" başlıklı doktora tezinin ilgili bölümleri yeniden ele alınarak hazırlanmıştır.

\begin{abstract}
2 Dr., Adana, Türkiye, sedagugercin@gmail.com
\end{abstract}

ORCID: 0000-0002-8338-7903

${ }^{3}$ Prof. Dr., Kurgizistan-Turkiye Manas Üniversitesi, Bişkek, Kırgızistan, mfedai.chavush@manas.edu.kg

Prof. Dr., Osmaniye Korkut Ata Üniversitesi, Osmaniye, Türkiye, mfcavus@osmaniye.edu.tr

ORCID: 0000-0002-2515-5805

\section{Sorumlu Yazar/Corresponding Author:}

Seda Güğerçin, Adana, Türkiye, sedagugercin@gmail.com

Başvuru/Submitted: 10/01/2021

Revizyon/Revised: 14/02/2021

Kabul/Accepted: 27/02/2021

Yayın/Online Published: 25/03/2020

Atıf/Citation: Güğerçin, S., \& Çavuş, M.F., Yıkıcı yönetim, sanal kaytarma ve işteki üretkenlik: Banka çalışanları üzerine bir araştırma, bmij (2021) 9 (1): 164-185, doi: https://doi.org/10.15295/bmij.v9i1.1745

\section{Öz}

$\mathrm{Bu}$ çalışmanın amacı; yıkıcı yönetim algısı, sanal kaytarma davranışları ve işteki üretkenlik kavramları arasındaki ilișkilerin yapılan ampirik bir araștırma ile ortaya konulmasıdır. Araștırmanın kuramsal çerçevesini, sosyal mübadele teorisi oluşturmaktadır. Çalı̧̧manın verileri Adana ilinde faaliyet gösteren kamu ve özel banka çalışanlarından anket yöntemi ile temin edilmiştir. Araștırma kapsamında temin edilen veriler; doğrulayıcı faktör analizi ve yapısal eşitlik modellemesi ile incelenmiştir. Çalışmada, yıkıcı yönetim algısının işteki üretkenlik ve sanal kaytarmanın önemli ve önemsiz olarak adlandırılan her iki boyutu ile anlamlı ilişkilerinin olduğu bulgulanmıştır. Yıkıcı yönetimin işteki üretkenliği negatif yönde, sanal kaytarmanın her iki boyutunu ise pozitif yönde etkilediği görülmüştür. Ayrıca, sanal kaytarma davranışının her iki boyutunun işteki üretkenlik ile ilişkisinin anlamlı olmadığı bulgulanmıştır. Bu çalışma sonuçlarına bağlı olarak, işletmelerdeki yöneticilere yıkıcı yönetimin olası zararlarına yönelik bilgilendirici eğitimler verilerek yıkıcı yönetim uygulamalarının önüne geçilmesi önerilmektedir. İlaveten işletmeler sanal kaytarma davranışlarına yönelik güvenlik açı̆̆ı oluşturmayacak şekilde kısmi esneklikte bir kısıtlama politikası uygulayabilir ve üretkenlik için tehdit olarak gördükleri spesifik sanal kaytarma davranışlarını takip ederek gerektiğinde ilave önlemler alabilirler.

Anahtar Kelimeler: İşteki Üretkenlik, Yıkıcı Yönetim, Sanal Kaytarma, Siber Kaytarma, Sanal Aylaklık

Jel Kodlari: M12

\begin{abstract}
The purpose of this research is to explore the relationships between cyberloafing, abusive supervision, and productivity at work through an empirical research within the framework of Social Exchange Theory. The data of the research were gathered from public and private bank employees working in Adana by survey method. The data, which was provided within the scope of the research, was examined with confirmatory factor analysis and structural equation modelling. In the study results, it is seen that abusive supervision positively affects cyberloafing and has negative effects on productivity at work. In addition, both dimensions of cyberloafing are found to be negatively correlated with productivity at work. Due to the results, it is recommended to prevent abusive supervision by giving informative training to managers about the possible harmful effects of abusive supervision. Additionally, organizations can impose restrictive policies and follow specific cyberloafing behaviors that they see as a threat to productivity and take additional precautions as needed.
\end{abstract}

Keywords: Productivity at work, Abusive Supervision, Cyberloafing, Cyberslacking

Jel Codes: M12 


\section{Extended Abstract}

\section{Abusive supervision, cyberloafing, and productivity at work: a study on bank employees}

\section{Literature}

\section{Research subject}

In this research, the effect of abusive supervision, which is seen widely in today's businesses, and the effect of cyberloafing, widespread with developing technology and causes high cost and efficiency losses, on productivity at work were analyzed. Additionally, the association between abusive supervision and cyberloafing was analyzed as well. The concept of productivity at work can be explained by expressions such as participation in the work environment, quality of work performed, employees' performance capacity, and the level of individual performance regarding personal factors (Coker, 2011, 240). Cyberloafing uses the organisation's internet access by employees during working hours for non-business purposes (Lim, 2002, 675). Abusive supervision was described by Tepper $(2000,178)$ as "... employees; personal evaluations of the manager's continuously hostile behaviours, which are verbal and do not contain physical violence".

\section{Research purpose and importance}

The purpose of this research is to explore the relationships between cyberloafing, abusive supervision, and productivity at work through an empirical research within the framework of Social Exchange Theory. The importance of the study lies in the fact that it includes current issues. Additionally, the data is obtained from employees in the banking industry, which has the largest share in Turkey's financial sector. Lastly, to the best of the authors' knowledge, no study has been found in the literature regarding the association between cyberloafing, abusive supervision, and productivity at work.

\section{Contribution of the article to the literature}

The findings of the study are expected to contribute to filling the gap in the literature as well as to guide researchers who are interested in these subjects and who are planning to conduct studies on them.

\section{Design and method}

\section{Research type}

In this research, quantitative data collection method has been used.

\section{Research problems}

Does cyberloafing affect productivity at work? Is abusive supervision an obstacle to productivity at work? Is abusive supervision increasing cyberloafing?

\section{Data collection method}

The data included in the study were gathered by survey method. Data were collected using convenience sampling at the initial phase, and then the snowball sampling method was applied.

\section{Quantitative analysis}

Preliminary analysis, confirmatory factor analysis (CFA), and structural equation modelling (SEM) methods were used in the analysis.

\section{Research model}

The research model is as follows.

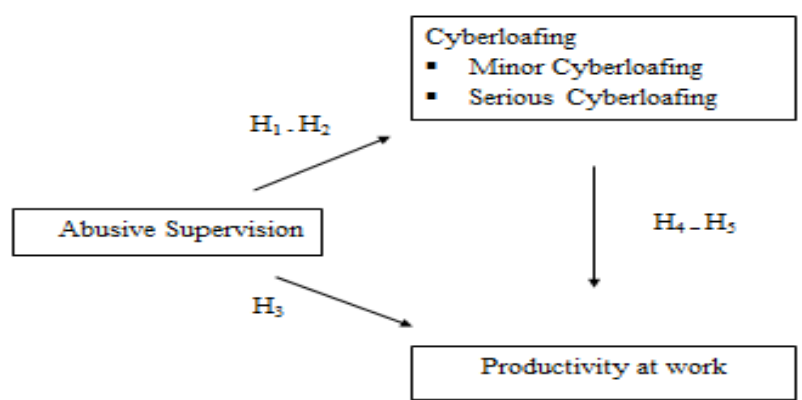

Figure 1. Research Model

\section{Research hypotheses}

The hypotheses of the research are as follows.

$\mathrm{H}_{1}$ : Abusive supervision has a positive effect on minor cyberloafing.

$\mathrm{H}_{2}$ : Abusive supervision has a positive effect on serious cyberloafing. 
$\mathrm{H}_{3}$ : Abusive supervision has a negative effect on productivity at work.

$\mathrm{H}_{4}$ : Minor cyberloafing has a negative effect on productivity at work.

$\mathrm{H}_{5}$ : Serious cyberloafing has a negative effect on productivity at work.

Findings and discussion

Findings as a result of the analysis

As a result of CFA and SEM analyses, it is seen that the data fit the established model.

Hypothesis test results

$\mathrm{H} 1, \mathrm{H} 2$, and $\mathrm{H} 3$ were supported, whereas $\mathrm{H} 4$ and $\mathrm{H} 5$ were not supported. Namely, the effects of serious and minor cyberloafing on productivity at work were not statistically significant.

\section{Discussing the findings with the literature}

In the literature, when the direct and indirect relationships between abusive supervision and cyberloafing were analyzed, it is found that abusive supervision has a positive effect on cyberloafing (Chiu \& Peng 2008; Davis-Blake, Broschak, \& George, 2003; Ezeh, Etodike, \& Chukwura, 2018; Martinko, Harvey, Brees, \& Mackey, 2013; Robinson \& Bennet, 1995; Sezici \& Güven, 2017; Turnley \& Feldman 1999; Wang, Mao, Wu, \& Liu, 2012; Yıldız H., Yıldız, B., \& İyigün, 2006). The result of this study was also seen to be in line with the literature.

In the literature, the widely accepted view on the relationship between abusive supervision and productivity at work is that abusive supervision meaningfully and negatively affects productivity at work (Chiu \& Peng, 2008; Davis-Blake et al., 2003; Harris, Kacmar, \& Zivnuska, 2007; Jones, 2009; Martinko, Harvey, Brees \& Mackey, 2013; Robinson \& Bennet, 1995; Turnley \& Feldman 1999: 907; Serdar \& Özsoy, 2019). The result of this study was also found to be similar to the studies in the literature.

According to the results of the analysis, no significant effect was found between the dimensions of cyberloafing and productivity at work. This finding is in line with Mashal (2017). Some studies found that cyberloafing negatively affects productivity at work (Buyruk Akbaba, 2019; Demir, Ürek \& Uğurluoğlu, 2017; Hussain \& Parida, 2017; Jiang, 2020; Kuschnaroff \& Bayma, 2014; Lim, Teo, \& Loo, 2002; Mercado, Giordano \& Dilchert, 2017; Shaddiq, Haryono, Muafı \& Isfianadewi, 2021). On the other hand, some studies found the opposite, namely stating that the effect of cyberloafing on productivity at work is positive (Blanchard \& Henle, 2008; Keklik, Kılıç, Yıldız H., \& Yıldız, B., 2015; Koay ve Soh, 2018; Saleh, Daqqa, Abdulrahim, \& Sakallah, 2018; Sao, Chandak, Patel \& Bhadade, 2020; Weissenfeld, Abramova \& Krasnova, 2019). In this context, the lack of a significant relationship between the two variables can be linked to a lack of clear consensus in the literature. In addition, this situation is thought to be related to the effect of social desirability, which is defined as a tendency of individuals to show themselves as liked or with desired characteristics. Due to the possibility of social desirability, participants may not have associated cyberloafing with their own behaviours.

\section{Conclusion, recommendation, and limitations \\ Results of the article}

In the study results, it is seen that abusive supervision positively affects cyberloafing and negatively affects productivity at work. This finding can be evaluated within the framework of the reciprocity principle of Blau's (1964) Social Exchange Theory. In addition, although both dimensions of cyberloafing are negatively correlated with productivity at work, the insignificant effects of cyberloafing on work productivity may be attributed to both the unrevealed (positive or negative) effects of cyberloafing on work productivity in the literature and the possible effect of social desirability.

\section{Suggestions based on results}

For practitioners, it is recommended to control abusive supervision by giving informative training to managers about the possible harmful effects of abusive supervision. Additionally, organizations can impose restrictive policies (Holguin, 2016; Jandaghi, Alvani, Zarei Matin, \& Fakheri 2015; Piotrowski, 2012; Rahimnia \& Mazidi, 2015) and follow specific cyberloafing behaviours that they see as a threat to productivity and take additional precautions as needed.

For researchers, it is also useful for researchers who discuss sensitive topics such as cyberloafing in their studies to measure the effect of social desirability. In addition, this study was conducted in a specific region and with a limited sample. Hence, the results of the analysis may vary in different samples. For this reason, the relationships among variables can be examined by providing the participation of various sector employees with a broader sample. Also, during the COVID-19 period, it is seen that working hours become more flexible with the start of alternate working from home. This flexibility creates a new framework, which may lead to redefining the main components of cyberloafing, such as the organisation's internet during working hours. For this reason, alternate work from home should be considered as a restriction in cyberloafing studies to be carried out in the future.

\section{Limitations of the article}

In this study, abusive supervision and cyberloafing were addressed as predictors of work productivity. Other potential predictors that may have an impact on productivity at work are omitted. To the best of the authors' knowledge, no study has been found in the literature regarding the association between cyberloafing, abusive supervision, and productivity at work. This deficiency can prevent the results of the research from being compared with different study results and discussing similar aspects of research. Additionally, the research was carried out with a limited sample covering a single industry and a single province. Given that the results may vary in different samples; it should be indicated that the results are limited to the sample in which the data were collected. 


\section{Giriş}

Üretkenlik kavramının ve örgüt için öneminin, 20. yüzyılın başında Frederick Winslow Taylor'un sıklıkla üretkenlik artışı sağlamaya yönelik çalışmalar yapması ile ön plana çıktığı söylenebilir (Buyruk, 2018, s. 604). Bu tarihten itibaren ise üretkenliği etkileyen birçok faktörün varlığı gün ışığına çıkmıştır. Teknolojinin yaygınlaşması ve internet kullanımının artışı sonucu, örgütlerin toplam üretkenliğinin de aynı doğrultuda hatta daha yüksek bir seviyede artması beklenmektedir. Ancak çoğu örgütteki teknolojik gelişme ve bu gelişmelere paralel olarak gerçekleştirilen yatırımların, bu doğrultuda çaba sarf eden örgütlerin piyasa payını olumlu yönde etkilemediği, ayrıca çalışanların da bilgi ve üretkenliklerini geliştirmediği izlenmektedir (Demir, Ürek ve Uğurluoğlu, 2017, s. 293).

Özellikle 1990'lı yılların sonlarına doğru internet erişiminin yaygınlaşması ve internet kullanımının artması, çalışanların mesai saatleri içerisinde iş dışı internet faaliyetlerinde bulunmalarını ifade eden (Lim, 2002, s. 676) sanal kaytarma kavramını ortaya çıkarmıştır. Başka bir ifade ile iletişim hızındaki artış ve bilgiye erişim kolaylığı, örgütler açısından işlerin doğru ve akıcı bir şekilde gerçekleştirilmesini desteklerken, çalışanların da kendi hayatlarına çalışma masalarından vakit ayırabilmelerine olanak sağlamıştır. Bu durum örgütlerin zaman zaman oldukça yüksek maliyetleri yüklenmesine sebep olmaktadır. Öyle ki sanal kaytarmanın 2005 yılında yalnızca Amerika Birleşik Devletleri'ndeki işletmelere toplam maliyetinin yıllık 178 milyar dolar olduğu hesaplanmıştır (Saalfield, 2005). ABD'de bir araştırma şirketinin yaptığı çalışmada ise sanal kaytarmanın ABD'deki işverenlere maliyetinin personel başına yıllık yaklaşık 4.500 dolar olduğu belirtilmiştir (MySammy, 2013). Bu maliyetler de göz önüne alındığında dış çevre faktörlerinden teknolojik çevrenin, işletmelerin ürün ya da hizmet üretimine direkt etkisi yanında dolaylı olarak da etki ettiği görülmektedir.

Üretkenliğe etki eden bir başka unsur da örgütün iç çevresindeki yönetici faktörüdür. Her ne kadar literatürde, yöneticilerin pozitif özellikleri ile alakalı yaygın çalışmalar olduğu görülse de geçmişte ve günümüzde örgütlerde yıkıcı yönetici örnekleri de görülmektedir. Tepper (2007, s. 262), yıkıc1 yönetimin $\mathrm{ABD}$ şirketlerine maliyetinin (işten ayrılma, sağlık harcamaları ve üretim kaybı gibi sonuçlarla) yıllık 23,8 milyon dolar olduğunun tahmin edildiğini belirtmiştir. Literatürde yıkıcı yönetimin; üretim kaybı, ciro ve sağlık harcamalarında artış, işten ayrılma, işe geç gelme ya da devamsızlık gibi olumsuz sonuçlara yol açtığı saptanmıştır (Akgeyik, Güngör, Uşen ve Umay, 2007; Thau ve Mitchell, 2010; Tepper, Moss ve Duffy, 2011).

Literatürde; işteki üretkenlik, yıkıcı yönetim ve sanal kaytarma kavramları arasındaki ikili ilişkilerin doğrudan veya dolaylı olarak incelendiği görülmüştür. Yıkıcı yönetim ve işteki üretkenlik arasındaki ilişkiyi inceleyen çalışmaların sonucunda ortaya çıkan genel bulgu, yıkıcı yönetimin işteki üretkenliği negatif yönde etkilediğidir (Martinko, Harvey, Brees ve Mackey, 2013; Robinson ve Bennet, 1995; Serdar ve Özsoy, 2019). Çalışanların sanal kaytarma davranışı sergilemelerinin işteki üretkenlikleri üzerindeki etkisini inceleyen çalışmalarda ise sonuçların farklılaşttğı görülmüştür. Sanal kaytarma ve üretkenlik ilişkisinin ağırlıklı olarak negatif yönlü olduğu tespit edilmiştir (Achakul ve Yolles, 2013; Demir ve diğerleri, 2017; Kuschnaroff ve Bayma, 2014; Lim, Teo ve Loo, 2002; Moody ve Siponen, 2013; Niaei, Peidaei ve Nasiripour, 2014; Rahimnia ve Mazidi, 2015; Sharma ve Gupta, 2004; Vitak, Crouse ve LaRose, 2011). Ancak sanal kaytarmanın üretkenlik üzerindeki pozitif yönlü etkisine yönelik bulgulara da rastlanılmıştır (Anandarajan, Paravastu ve Simmers, 2006; Coker, 2011; Oravec, 2002). Dolayısıyla literatürde, sanal kaytarmanın üretkenliği pozitif mi yoksa negatif mi etkilediğine yönelik görüş birliğine varılamadığı söylenebilir. Yıkıcı yönetimin ise sanal kaytarma davranışlarını gerek doğrudan gerekse dolaylı olarak pozitif yönde etkilediği bulgulanmıştır (Chiu ve Peng 2008; Davis-Blake ve diğerleri, 2003; Ezeh, Etodike, ve Chukwura, 2018; Martinko ve diğerleri, 2013; Robinson ve Bennet, 1995; Sezici ve Güven, 2017; Turnley ve Feldman 1999; Wang, Mao, Wu ve Liu, 2012; Yıldız H., Yıldız, B., ve İyigün, 2006).

$\mathrm{Bu}$ çalışmada, Sosyal Mübadele Teorisi çerçevesinde, yıkııı yönetim algısı, sanal kaytarma davranışları ve işteki üretkenlik kavramları arasındaki ilişkilerin yapılan ampirik bir araştırma ile ortaya konulması amaçlanmaktadır. Yapılan araştırma kapsamında şu sorulara yanıt aranmıştır: "Yıkıcı yönetim, sanal kaytarma davranışı ile işteki üretkenliği ne yönde etkilemektedir?", "Sanal kaytarma davranışları işteki üretkenliği etkilemekte midir?" Çalışma kapsamında Adana ilinde faaliyet gösteren kamu ve özel banka çalışanlarından anket yolu ile veri temin edilmiştir. Çalışma örneklemi olarak finans sektöründeki en büyük pay sahibi olan banka sektörü çalışanlarının (Özince, 2008 , s. 25) seçilmesinin sebebi, bu çalışma sonuçlarına bağlı olarak çalışanlara yönelik yapılabilecek yeni uygulamaların bankaların kurumsallaşma çabalarından hareketle diğer sektörlere de ilham 
verebileceği ve öncülük edebileceği düşüncesidir. Çalışma verilerinin banka sektörü çalışanlarından temin edilmesi, çalışmanın güncel konuları içermesi ve daha önce bu üç değişkenin yer aldığı bir çalışmaya rastlanılmamış olmasının çalışmanın özgün değerini arttırdığı düşünülmektedir. Ayrıca yapılan çalı̧̧ma ile elde edilen bulguların gerek yazındaki boşluğu doldurmaya katkı sağlaması gerekse de Adana ilinde çalışan banka yöneticilerine ve bu alanda çalışma yapmayı planlayan araştırmacılara kılavuz olması umut edilmektedir.

\section{Literatür incelemesi}

\section{Yıkıcı yönetim}

Yıkıcı yönetim kavramı, "Çalışanların; yöneticinin devamlı surette gerçekleştirdiği, sözlü olan ve fiziksel şiddet barındırmayan düşmanca davranışlarına yönelik kişisel değerlendirmeleri" olarak ifade edilmiştir (Tepper, 2000, s. 178). Bu bağlamda, yıkıcı yönetimin üç temel özelliği bulunmaktadır. Bunlar, yıkıcı yönetimin sürekli bir şekilde gerçekleşmesi, fiziksel şiddet içermemesi ve öznel değerlendirmelere tabi olmasıdır. Örgütlerin esas görevlerinden uzaklaşmasında ve çalışanların motivasyonlarının azalmasında yıkıcı yönetimin payı olduğu düşünülmektedir. Literatürde istismarc1 yönetim (Serdar ve Özsoy, 2019; Ülbeği, Özgen, H. M. ve Özgen, H., 2014) olarak da yer alan yıkıcı yönetim, uygulamada farklı şekillerde gerçekleşebilir. Yöneticinin; çalışanı toplum içinde alay konusu yapması, dalga geçmesi, çalışanların başarılarını üzerine alması, çalışanlara karşı kaba davranışlar sergilemesi, çalışanları işi ile tehdit etmesi ve öfkeli göz teması (Harvey ve Keashly, 2003; Tepper, 2007; Tepper, Duffy, Henle ve Lambert, 2006) gibi davranışlar yıkıcı yönetim kapsamında ele alınmaktadır. İş hayatında da yıkıcı yönetimin yaygın olduğu bilinmektedir. Dolayısıyla, yıkıcı yönetim uygulamalarına maruz kalan çalışan davranışlarının incelenmesi gerekliliği ortaya çıkmaktadır.

\section{Sanal kaytarma davranışı}

İnternet erişiminin yaygınlaşması internet kullanımının artışını da beraberinde getirmiştir. İş̧ yerlerinde erişim sırasında nispeten daha az kesinti olması ve kota sorunu yaşanmaması gibi nedenler çalışanları iş yerinde internet kullanımı konusunda motive etmektedir. Ayrıca, iş yerlerinde internetin hızlı ve düşük maliyetli bir iletişim kanalı olarak kullanılmaya başlanması (Yağcı ve Yüceler, 2016, s. 535) sanal kaytarma olarak adlandırılan yeni bir kavramın oluşmasına zemin hazırlamıştır.

Sanal kaytarma literatürde, siber aylaklık, siber kaytarma ve sanal tembellik olarak da ifade edilmektedir (Candan ve İnce, 2016, s. 229; Kaplan ve Ögüut, 2012, s. 2; Kurt, 2011, s. 22; Örücü ve Yıldız, 2014, s. 99; Özkalp, Aydın ve Tekeli, 2012, s. 18). Sanal kaytarma, çalışma saatleri dahilinde çalışanların örgütün internet erişimini iş ile ilgili olmayan amaçların gerçekleştirilmesine yönelik kullanması (Lim, 2002, s. 675) olarak tanımlanmıştır. Klotz ve Buckley (2013, s. 114) de sanal kaytarmanın, yalnız örgüt bünyesindeki teknolojik aygıtların kullanılmasıyla ortaya çıkmadığını, çalışanların kişisel mobil aygıtları ile de internet erişimlerini bireysel amaçlarını gerçekleştirmek için kullandıklarını belirtmişlerdir.

Literatürde sanal kaytarma davranışlarının birçok farklı şekilde sınıflandırıldığı görülmekle birlikte bu çalışmada, Blanchard ve Henle' nin (2008) sanal kaytarma davranışlarını önemli ve önemsiz olarak iki boyutta değerlendirdiği araştırma çerçevesinde ilerlenmiştir. Söz konusu durumda araştırmada ele alınan boyutların literatürde genel kabul görmesi ve sıkça kullanılması etkili olmuştur. Önemsiz sanal kaytarma davranışları; kişisel e-posta alma-gönderme, spor, haber, finans ve borsa sitelerini takip etme olarak özetlenebilir. Önemli sanal kaytarma davranışlarını ise yetişkin odaklı siteleri ziyaret etme, bahis oynama, sosyal medya platformların ve sanal toplulukların ziyaret etme gibi davranışlar oluşturmaktadır (Blanchard ve Henle, 2008).

\section{İşteki üretkenlik}

Literatürde birçok tanımı bulunan üretkenlik, ilk olarak Fransızcada kullanılan produire kökü ile türetilmiş olup, Türkçe'de de üretmek fiilinden türemiştir. Üretebilme yeterliliği olarak da açıklanabilir. Üretebilme yeterliği diğer bir deyişle üretkenlik, üretimde ürünün parça başına çeşitlendirilmesi ve adedinin artması olarak ifade edilebilir (Ergül, 1999, s. 286). Kobu (1987) ise üretkenliğin üretim faktörlerini maksimum elverişlilikle kullanarak elde edilen üretim miktarı şeklinde tanımlanabileceğini belirtmiştir. Üretim faktörleri özensiz kullanıldığında, ortaya çıan üretim miktarı da bu durumdan şüphesiz etkilenecektir. Bu sebeple üretim zincirinin her bir halkasında gösterilen azami özen sonucunda maksimum fayda elde edilebilecektir. Başka bir deyişle, üretkenlik kavramı her bir girdi başına çıkıı olarak (Camus, 2007, s. 19) ya da her bir parça başı mala harcanan maliyet veya zaman gibi ölçütlerle de belirtilebilir (Toprak 2005, s. 381; Yeşilyurt 
2009, s. 138). İşte üretkenlik kavramı ise; çalışma ortamında işe katılım, gerçekleştirilen iş kalitesi, çalışanların performans kapasitesi ve kişisel faktörlere ilişkin gösterilen bireysel performansın düzeyi gibi ifadelerle açıklanabilir (Coker, 2011, s. 240).

\section{Kuramsal çerçeve}

Sosyal Mübadele Teorisi, bu çalışma kapsamında yer alan yıkıcı yönetim algısı, sanal kaytarma davranışı ve işteki üretkenlik kavramları arasındaki ilişkileri değerlendirebilecek bir çerçeve sunmaktadır. Sosyal mübadele teorisine göre; kişilerin saygı, kabul ve onay görme, onur duyma ve dikkate alınma gibi beklentilerle ilişkiye girdikleri ve ilişkiyi korudukları belirtilebilir. Bu ilişkiyi sürdürmek için kimi zaman çeşitli tavizler verdikleri, kimi zaman da ilave sorumluluklar aldıkları söylenebilir (Ertürk, 2015, s. 36).

Blau (1964)'ya göre sosyal mübadeleler gayri resmi ilişkilerden kaynaklanır ve bu ilişkiler de güven ve karşılıklılık üzerine kuruludur. Bu teori çerçevesinde, karşlıklılık ilkesi (norm for reciprocity) gereği, insanların kendilerine olumlu yaklaşılması durumunda olumlu tutum sergileyecekleri beklenmektedir (Gouldner, 1960, s. 165). Bu durum tam tersi için de geçerlidir. Kişiler olumsuz algıladıkları bir davranışla karşılaştığında veya belirli bir davranış karşısında zarar gördüklerini düşündüklerinde, karşılık olarak olumsuz tepkiler vermektedirler. Dolayısıyla yıkıcı yönetim ve olumsuz çıktılarının incelenmesi noktasında, sosyal mübadele teorisinden faydalanılabilir.

Sosyal mübadele teorisinin karşılıklılık ilkesi gereği yıkıcı yönetim, yöneticiler ve çalışanlar arasındaki karşılıklı etkileşimin kalitesini düşürmesi beklenmektedir (Tepper, 2000). Nitekim yıkıcı yönetim ve olumsuz çıktıları arasındaki ilişki, pek çok araştırmada sosyal mübadele teorisi ile açıklanmıştır (Aryee, Chen, Sun ve Debrah, 2007; Cropanzano ve Mitchell, 2005; Mitchell ve Ambrose, 2007; Skarlicki ve Folger, 1997; 2004; Tepper, 2000). Dolayısıyla, bu teori kapsamında yıkıcı yönetime maruz kalan çalışanların üretkenlik karşıtı hatta sapkın davranışlara yönelmesi ve/veya işteki üretkenliklerinin negatif yönde etkilenmesi de beklenmektedir.

\section{Metodoloji}

\section{Araştırma modeli ve hipotezler}

Yapılan araştırma kapsamında şu sorulara yanıt aranmıştır: Gelişen teknoloji ile yaygınlaşan ve çalışma saatleri içerisinde internetin iş dışı amaçlarla kullanılması anlamına gelen sanal kaytarma davranışları, işteki üretkenliği etkilemekte midir? Yöneticilerin çalışanlara karşı gösterdikleri fiziksel olmayan sadist ve tiran davranışlar olarak açıklanan yıkıcı yönetim, işteki üretkenliğe engel midir? Yıkıcı yönetim sanal kaytarma davranışlarını arttırmakta mıdır? Araştırma sorularının yanıtlanması amacıyla kurulan hipotezleri içeren ve çalışmadaki kavramlardan oluşan araştırma modeli Şekil 1'de gösterilmiştir.

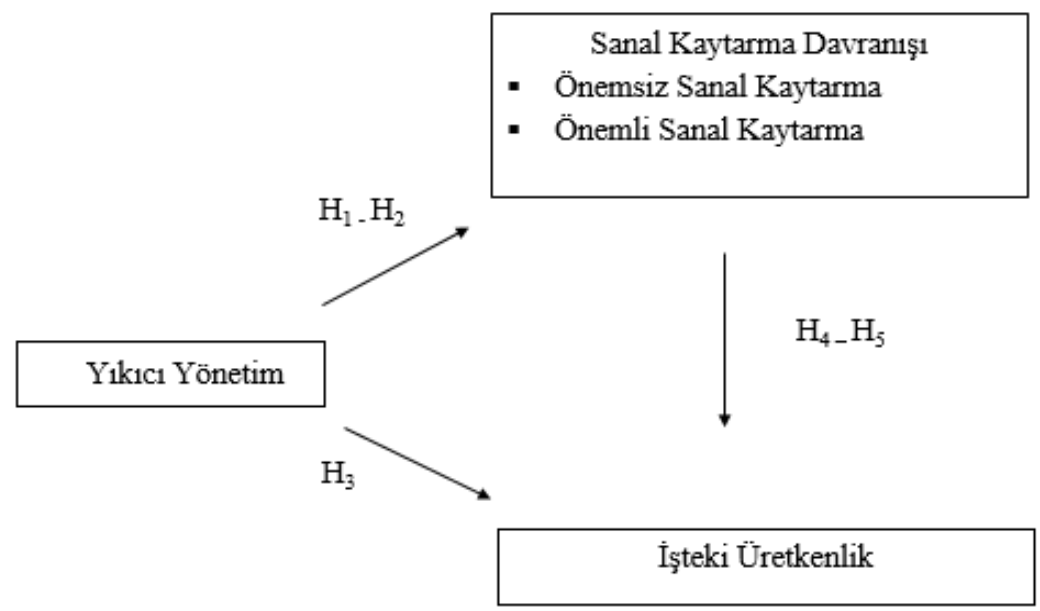

Şekil 1. Araştırmanın modeli

Araştırmanın hipotezleri aşağıdaki şekilde oluşturulmuştur: 
$\mathrm{H}_{1}$ : Yıkıcı yönetim, önemsiz sanal kaytarma davranışlarını pozitif yönde etkilemektedir.

$\mathrm{H}_{2}$ : Yıkıcı yönetim, önemli sanal kaytarma davranışlarını pozitif yönde etkilemektedir.

$\mathrm{H}_{3}$ : Yıkıcı yönetim, işteki üretkenliği negatif yönde etkilemektedir.

$\mathrm{H}_{4}$ : Önemsiz sanal kaytarma davranışı, işteki üretkenliği negatif yönde etkilemektedir.

$\mathrm{H}_{5}$ : Önemli sanal kaytarma davranışı, işteki üretkenliği negatif yönde etkilemektedir.

\section{Ölçekler}

Çalı̧̧mada yer alan veriler anket yöntemi ile toplanmıştır. Sanal kaytarma davranışı değişkeninin ölçümü için Blanchard-Henle (2008)'nin geliştirdiğii, “Correlates of Different Forms of Cyberloafing: The Role of Norms and External Locus of Control" adlı makalede yer alan sanal kaytarma ölçeği orijinal form olarak baz alınmıştır. Kaplan ve Öğüt (2012) ve Kaplan ve Çetinkaya (2014)'nın çalışmalarında test edilmiş olan ölçeğin Türkçe versiyonu, Candan ve İnce (2016)'nin çalışmasından alınmıştır. Ölçekteki son ifade ise (Mesai saatleri içinde sosyal medya platformlarını (Twitter, Facebook, Instagram vb.) ziyaret eder) araştırmacı tarafından veri toplama aracına dahil edilmiştir. Ölçeğe soru eklenmesine yönelik yazardan onay alınmıştır. Çalışmada incelenen ikinci değişken olan yıkıcı yönetim kavramı ise, Tepper (2000)'ın geliştirdiği ve tek boyuttan meydana gelen yıkıcı yönetim ölçeğiyle ölçülmüştür. Ölçeğin Türkçe versiyonu, Ülbeği, Özgen, H.M ve Özgen, H. tarafından 2014 yılında gerçekleştirilen “Türkiye'de İstismarcı Yönetim Ölçeğinin Uyarlaması: Güvenirlik ve Geçerlik Analizi" adlı çalışmadan alınmıştır. Ölçeğe ilave olarak bir ifade daha (İşle ilgili eksik bilgi verir.) araştırmacı tarafından veri toplama aracına eklenmiştir. Ölçeğe soru eklenmesine yönelik yazardan onay alınmıştır. İşteki üretkenlik kavramı ise Endicott ve Nee (1997) tarafından geliştirilen ve tek boyuttan oluşan Endicott İşte Üretkenlik Ölçeği temel alınarak değerlendirilmiştir. Ölçek, Uğuz, İnanç, Yerlikaya ve Aydın (2004) tarafından Türkçe'ye uyarlanmış olup, Endicott İşte Üretkenlik Ölçeği' nin (EIÜÖ) “Türk Toplumunda Geçerlilik ve Güvenilirliğinin Değerlendirilmesi" adlı çalışmadan alınmıştır. Ölçek toplamda 25 ifadeden oluşmaktadır. Banka çalışanlarının oldukça uzun ve yoğun mesai saatleri göz önüne alınarak, veri toplama sürecinin etkin şekilde yürütülmesi amacıyla anket formu uygulaması öncesinde bir odak grup çalışması düzenlenmiştir. Bu doğrultuda sektörde bulunan çalışanlardan uzman görüşü alınmış olup İşteki Üretkenlik Ölçeği'nde yer alan bazı maddelerin katılımcılar tarafından anlaşılır bulunmadığına ve/veya bankacılık sektöründe gerçekleştirilen işlerle ilgili olmadığına yönelik geri bildirim alınmıştır. Buradan hareketle, ilgili maddeler ölçekte yer almadan işteki üretkenlik değişkeninin ölçülmesi konusunda, ölçeğin Türkçe geçerlilik ve güvenirliğini test eden araştırmacılardan onay alınmış ve işteki üretkenlik değişkeni 17 ifade ile ölçülmüştür. Anket formunda tüm ölçekler 5'li Likert tipi ölçme düzeyi ile yer almıştır. Bu bilgiler ışığında, 51 maddelik bir anket formu uygulanmıştır ve anketin son kısmında demografik sorulara yer verilmiştir.

\section{Evren ve örneklem}

Çalışmanın evrenini, Adana ilindeki banka çalışanları oluşturmaktadır. Türkiye Bankalar Birliği'nin ve Türkiye Katılım Bankaları Birliği'nin internet sitelerinden Adana ili verileri incelendiğinde 2020 Ocak ayı verilerinde katılım bankaları dahil, Türkiye'de faal olan 52 adet bankanın 28 adedinin Adana'da aktif olarak çalıştığı bilgisi edinilmiştir. Ülke genelindeki katılım bankaları dahil toplam 11.361 adet şubenin 243'ü de Adana ilinde bulunmaktadır. İldeki toplam banka personel sayısı ise 3.751 olarak belirtilmiştir. Bu araştırmada 317 banka çalışanına ulaşılmış olup, faktör analizi için örneklem sayısının ankette yer alan ifade sayısının en az beş katı olması gerekliliği dikkate alındığında (Büyüköztürk, Kılıç Çakmak, Akgün, Karadeniz ve Demirel, 2014), bu sayının faktör analizi için yeterli olduğu söylenebilir. Bu araştırmada ilk etapta kolayda örnekleme yoluyla yakın çevrede olan, kolay ulaşılabilen, elde mevcut ve araştırmaya gönüllü katılmak isteyen banka çalışanları katılmışlardır. Sonrasında ise zincir (kartopu) örnekleme yönteminden yararlanılarak bu katılımcıların referansları ile örneklemi oluşturan diğer banka personelinden veri toplanmıştır. Veri toplama işlemi 2019 yılı Şubat ayında başlamış olup Kasım 2019'da sonlandırılmıştır. Bu sebeple etik kurul izin belgesi alınmamıştır.

\section{Bulgular}

\section{Ön analizler}

Yapılan araştırma kapsamında temin edilen verilerin analizinde bilgisayar destekli yazılımlar kullanılmıştır. Verilerin analizinde bu yazılımlar kullanılarak ön analizler, doğrulayıcı faktör analizi (DFA) ve yapısal eşitlik modellemesi (YEM) yöntemleri kullanılmıştır. Elde edilen araştırma bulgularının analize uygun olup olmadığının kontrolü için istatistiksel analizler yapılmadan önce veri 
setinin kontrol edilmesi ve böylece olası sorun ve hataların tespit edilerek verinin analize hazırlanması gerekmektedir (Tabachnick ve Fidell, 2013, böl. 11 ). Ön analizler kapsamında tek yönlü ve çok yönlü uç değer analizi ve Harman'ın tek faktör testi yapılmıştır. Ayrıca verilerin normal dağılım gösterip göstermediğinin tespiti için basıklık ve çarpıklık değerleri hesaplanmıştır.

Demografik değişkenler hariç her bir ölçek maddesine ait ortalama ve standart sapma değerleri karşılaştırıldıktan sonra veri setinin doğruluğunun tespit edilmesi amaciyla veri setinde uç değer (outlier) olup olmadığı da incelenmiştir. Her bir maddeye ait " $z$ " değerlerinin +3.29 ile -3.29 aralığında olması beklenmektedir. Aksi takdirde uç değerden söz edilebilmektedir (Tabachnick ve Fidell, 2013, böl. 11). İlgili analiz gerçekleştirilmiş ve 4 adet ifadeye ait " $z$ " değerlerinin +3.29 'dan büyük olduğu tespit edilmiştir. Bu ifadeler S9, S10, S12 ve S14 olup Tablo 1'de sunulmuştur.

Tablo 1. Verilere İlişkin Z Değerleri

\begin{tabular}{lcc}
\hline Değişkenler & Minimum & Z Değerleri \\
\hline Zscore(S9) & $-0,49$ & 3,71 \\
Zscore(S10) & $-0,48$ & 3,63 \\
Zscore(S12) & $-0,61$ & 3,37 \\
Zscore(S14) & $-0,56$ & 3,5 \\
\hline
\end{tabular}

Veri setindeki olası uç değerlerin incelenmesi ve belirlenmesi sonrasında uç değerlere ne yapılması gerektiğine karar verilmelidir. $\mathrm{Bu}$ kararın alınmasına yönelik literatürde farklı görüşler bulunmaktadır. Yılmaz ve Koğar'a $(2015$, s. 62) göre belirlenen uç değerler silinebilir, uç değerlere müdahale edilmeyebilir veya veri dönüşümleri gerçekleştirilebilir. Konuyu içeren literatürde her üç durumun da veriye uygulanması ve yapıyı en iyi ortaya koyan alternatifi kullanılmasinın uygun olacağı belirtilmiştir (Raykov ve Marcoulides, 2008). Bazı yazarlar uç değerlerin silinmesini savunurken bazıları da verilerin uç değerler silinmediğinde evreni daha iyi temsil ettiğini belirtmişlerdir (Orr, Sackett ve DuBois, 1991, s. 476). Bu görüş paralelinde tespit edilen uç değerlerin herhangi bir değişiklik yapılmadan araştırmada yer almasına karar verilmiştir.

Çok değişkenli ve yüksek hacimli veri setlerinde aykırı değerlerin tespitine yönelik gözlemler arası ilişkiye dayalı $\mathrm{p}<.001$ düzeyinde Mahalanobis ölçütü tavsiye edilmektedir (Çokluk, Şekercioğlu ve Büyüköztürk 2010, s. 25; Johnson ve Wichern, 2002, s. 21). Bu bilgiler doğrultusunda bilgisayar yazılımından Mahalanobis uzaklığı hesaplanmış ve bir anketin uç değer olarak tanımlandığı görülmüş̧ür. Bunun sonucunda, uç değer hesaplanan 1 anketin veri setinde bulunması (317 veri) ve çıkarılması durumunda (316 veri) çarpıklık basıklık analizi yapılmış ve Cronbach alfa değeri ölçülmüş̧ür. Her iki durumda da analiz sonuçlarında önemli bir fark oluşmadığı görülmüştür. Bu sebeple uç değer içeren 1 adet verinin analizden çıkarılmamasına karar verilmiştir.

Araştırmada ortak yöntem sapması, Harman'ın tek faktör testi ile ölçülmüştür. Bu bağlamda ölçekte yer alan bütün ifadelere döngüsüz faktör analizi yapılmıştır. Sonuçların değerlendirilme noktasında, ifadelerin tek bir boyutta toplanmadığı ve öz değeri 1'den yüksek toplam 6 boyut olduğu tespit edilmiştir. Ek olarak, döngüsüz faktör analizinde faktör sayısı 1'e sabitlendiğinde oluşan tek faktörün toplam varyansın çoğunluğunu değil, \%37'sine karşılık gelen düşük bir kısmını açıkladığı tespit edilmiştir. Elde edilen bulgulardan yola çıkılarak bu araştırmada ortak yöntem sapması olmadığı söylenebilir (Podsakoff, P. M., MacKenzie, Lee ve Podsakoff, N. P. , 2003, s. 889).

Verilerin normal dağılım gösterip göstermediğinin tespiti için; basıklık ve çarpıklık değerleri hesaplanmıştır. Basıklık ve çarpıklık katsayısının -3 ile +3 arasında olması normal dağılım olarak kabul edilebilir (Kalaycı, 2010, s. 58). Sanal kaytarma davranışı ölçeğindeki üç adet ifadenin (S9, S10, S14) basıklığının $3^{\prime}$ ün biraz üzerinde olduğu görülmektedir. Ancak basıklık değerinin üst sınırını \pm 7 olarak ele alan çalışmalar da mevcuttur (Bollen, 1998, s. 266-267; Hoyle, 1995, s. 163)

Yapılan analiz sonucunda tüm maddelerin kabul edilebilir sınırlar içerisinde olduğu görülmüş olup, Tablo 2'de gösterilmiştir. Verilerin normal dağılıma sahip olduğu sonucuna ulaşılmıştır. 
Tablo 2. Verilere İlişkin Normallik Testleri

\begin{tabular}{|c|c|c|c|c|c|}
\hline \multirow[t]{2}{*}{ Değişkenler } & \multicolumn{2}{|c|}{ Dağılımın Özellikleri } & \multirow[t]{2}{*}{ Değişkenler } & \multicolumn{2}{|c|}{ Dağılımın Özellikleri } \\
\hline & Çarpıklık & Basıklık & & Çarpıklık & Basıklık \\
\hline S1 & 0.05 & -1.20 & Y8 & 0.99 & -0.27 \\
\hline S2 & 0.42 & -0.81 & Y9 & 0.72 & -0.76 \\
\hline S3 & -0.02 & -0.95 & $\mathrm{Y} 10$ & 0.55 & -0.98 \\
\hline S4 & -0.12 & -1.00 & Y11 & 0.54 & -1.03 \\
\hline S5 & -0.06 & -1.25 & $\mathrm{Y} 12$ & 0.70 & -0.63 \\
\hline S6 & 0.40 & -0.99 & Y13 & 0.80 & -0.42 \\
\hline S7 & 0.32 & -1.28 & Y14 & 1.02 & -0.11 \\
\hline S8 & 0.47 & -1.02 & Y15 & 0.88 & -0.37 \\
\hline S9 & 2.38 & 5.27 & Y16 & 0.70 & -0.74 \\
\hline S10 & 2.24 & 4.31 & $\mathrm{U} 1$ & -0.38 & -0.8 \\
\hline S11 & 0.21 & -1.33 & $\mathrm{U} 2$ & -0.67 & -0.4 \\
\hline S12 & 1.80 & 2.62 & U3 & -0.42 & -0.78 \\
\hline S13 & 0.54 & -0.79 & U4 & -0.49 & -0.58 \\
\hline S14 & 1.96 & 3.36 & U5 & -0.23 & -1.1 \\
\hline S15 & 0.30 & -1.15 & U6 & -0.30 & -0.91 \\
\hline S16 & 0.50 & -0.90 & U7 & -0.83 & -0.20 \\
\hline S17 & -0.08 & -1.46 & U8 & -0.63 & -0.53 \\
\hline S18 & -0.30 & -1.35 & U9 & -0.6 & -0.58 \\
\hline Y1 & 1.03 & -0.07 & U10 & -0.34 & -0.68 \\
\hline Y2 & 0.95 & -0.04 & U11 & -0.87 & -0.08 \\
\hline Y3 & 1.00 & 0.02 & U12 & -0.30 & -0.92 \\
\hline Y4 & 0.85 & -0.38 & U13 & -0.41 & -0.91 \\
\hline Y5 & 0.71 & -0.79 & U14 & -0.56 & -0.71 \\
\hline Y6 & 0.64 & -0.72 & U15 & -0.24 & -1.05 \\
\hline \multirow[t]{2}{*}{ Y7 } & 0.44 & -0.81 & U16 & -0.24 & -1.06 \\
\hline & & & U17 & -0.26 & -1.09 \\
\hline
\end{tabular}




\section{Demografik özellikler}

Örneklemi oluşturan 317 banka çalışanından \% 51,7'sinin erkek, \% 48,3'ünün ise kadın olduğu gözlenmektedir. Demografik değişkenlerden yaş incelendiğinde örneklemin \%12,6'sının 24 yaş veya altında olduğu, \%49,2'sinin 25-34, \%34,7'sinin 35-44 yaş aralığında olduğu ve \%3,5'unun 45 veya daha yüksek yaşta olduğu görülmektedir. Örneklemin \%31,9'unun bekar, \%68,1'inin ise evli olduğu ortaya çıkmıştır. Eğitim düzeyleri yönüyle ise \%8,2'sinin lise, \%12,9'unun ön lisans, \%54,3'ünün lisans ve \%24,6'sının lisansüstü eğitimi aldıkları bulgulanmıştır. Örneklemin toplam iş tecrübelerine bakıldığında \%16,7'sinin 2 yıldan az, \%32,2'sinin 2 ile 8 yıl arası, \%34,4'ünün ise 9-14 yıl arası, $\% 12,6$ 'sının 15-20 yıl arası ve \%4,1'inin 20 yıldan daha fazla süredir çalıştıkları görülmüştür. Son olarak katılımcıların \%40,7'sinin kamu ve \%59,3'ünün ise özel sermayeli banka personeli olduğu bulgulanmıştır.

\section{Güvenilirlik analizi}

Güvenilirlik kavramı, bir ölçekte yer alan ifadelerin birbiri ile tutarlı olup olmadığını ve kullanılan ölçeğin, araştırılan sorunu ne düzeyde yansıttığını belirtmesi (Kalaycı, 2010, böl. 19) nedeniyle oldukça önemlidir. Bu araştırmada, Cronbach alfa katsayısının hesaplanması yöntemi ölçeklerin güvenilirliklerini ölçmek amacıyla tercih edilmiştir. Araştırma kapsamında kullanılan ölçeklere ve boyutlara ilişkin güvenilirlik katsayıları Tablo 3'te gösterilmiştir.

Tablo 3. Ölçeklerin ve Boyutlarının Güvenilirlik Katsayıları

\begin{tabular}{|c|c|c|}
\hline Ölçekler & İfade Sayısı & Cronbach Alfa (a) \\
\hline Sanal Kaytarma Davranışı Ölçeği & 18 & .92 \\
\hline Önemsiz Sanal Kaytarma Davranışı & 9 & .86 \\
\hline Önemli Sanal Kaytarma Davranışı & 9 & .87 \\
\hline Yıkııı Yönetim Ölçeği & 16 & .96 \\
\hline İşteki Üretkenlik Ölçeği & 17 & .96 \\
\hline
\end{tabular}

Güvenilirlik analizi sonuçlarından görüldüğü üzere ölçeklerin ve sanal kaytarma ölçeği boyutlarının hesaplanan Cronbach alfa katsayıları sosyal bilim araştırmalarında yeterli kabul edilen .70 değerinin üzerindedir (Churchill 1979, s. 68).

\section{Doğrulayıcı faktör analizi (DFA)}

Yapısal eşitlik modelinin kullanılacağı çalışmalarda öncelikle yapılar tanımlanır, faktör yapıları incelenir, sonrasında ise DFA yapılarak ölçüm modeli test edilmelidir. Akabinde uyum istatistikleri incelenmeli ve nihayetinde de karar verilen yolların katsayıları, standardize edilmiş hata terimleri, modifikasyon indeksleri incelenmeli ve analizde kullanılacak ölçüm modeline karar verilmelidir (Hair ve diğerleri, 2005 s. 759). Ardından, yapısal eşitliklerin analizine ve modellemesine geçilir. Bu çalışma kapsamında bahsedilen aşamalar uygulanmıştır.

DFA uygulanmasından sonra, ilk etapta parametrelerde, Hair ve diğerlerinin (2005 s. 796) önerisi doğrultusunda kabul edilebilir kriterleri sağlamayan tahminlerin (offending estimates) olup olmadığı incelenmiş ve herhangi bir kabul edilebilir kriterleri sağlamayan tahmin olmadığı görülmüştür. DFA sonucunda değerlendirilmesi gereken bir unsur da faktör yükleridir. Hair ve diğerleri $(2005$, s. 778)'ne göre standart regresyon katsayısı olarak da bahsedilen faktör yükleri için örneklem büyüklüğü göz önünde bulundurulmalıdır ve 200 örneklemde her bir değişken için faktör yükü minimum 0,30 olmalı aynı zamanda 0,50'nin üzerindeki faktör yüklerinin ise anlamlı olarak ifade edilmektedir. Bu araştırmada, faktör yükü .50'nin altında olan bir adet gözlenen değişken bulunmuştur. Bu bağlamda faktör yükü 0.39 olan ve önemli sanal kaytarma davranışı boyutunun altında bulunan maddelerden biri olan S10 (Mesai saatleri içinde yetişkin odaklı siteleri ziyaret eder.) modelden çıkarılmıştır. Sonrasında DFA tekrarlanmış ve faktör yükü 0,50'nin altında kalan hiçbir ifade kalmadığı görülmüştür. Faktör yüklerinin anlamlı olup olmadığının kontrolü akabinde, modifikasyon indeks değerleri incelenmiştir. İncelenen modifikasyon indeksleri sonucunda, önemsiz sanal kaytarma boyutu altında yer alan S5 ve S6 değişkenlerinin hata terimleri (e38 ve e37) arasındaki yüksek modifikasyon indeks değeri (M.I.: 140.22) olduğu görülmüştür. Bahsedilen hata terimleri arasında kovaryans sağlanmış ve model yeniden test edilmiştir. Modele bakıldığında faktör yükü 0.48 olan ve önemsiz sanal kaytarma davranışı boyutunun altında bulunan maddelerden S5 de modelden çıkarılmıştır. Sonrasında DFA tekrarlanmış ve faktör yükü 0,50'nin altında hiçbir ifade kalmadığı görülmüştür. Kabul edilebilir kriterleri sağlamayan tahminler, faktör yükleri ve modifikasyon değerleri ile alakalı analizlerin gerçekleştirilmesi akabinde ölçüm modelinin test sonuçları 
değerlendirilmiştir. Hair ve diğerlerinin (2014, s. 584) uyum iyiliği ölçütlerini gösteren çalışması, Tablo 4 'te yer alan referans değerleri için temel alınmıştır. Ek olarak, Hu ve Bentler (1999) de takip edilerek CFI, SRMR, RMSEA, TLI değerleri raporlanmıştır.

Tablo 4. Ölçüm Modeli Uyum İyiliği Sonuçları

\begin{tabular}{|c|c|c|c|}
\hline \multirow{2}{*}{$\begin{array}{l}\text { Uyum İyiliği } \\
\text { Ölçüitleri }\end{array}$} & \multicolumn{2}{|c|}{ Referans Değerler } & \multirow{2}{*}{$\begin{array}{l}\text { Ölçüm Modeli } \\
\text { Sonuçları }\end{array}$} \\
\hline & İyi Uyum & Kabul Edilebilir Uyum & \\
\hline $\mathrm{DF}(\mathrm{sd})$ & - & - & 1107 \\
\hline $\mathrm{CMIN}\left(\chi^{2}\right)$ & $0 \leq x^{2} \leq 2 s d$ & $2 \mathrm{sd} \leq \mathrm{x}^{2} \leq 3 \mathrm{sd}$ & 2325.81 \\
\hline $\mathrm{CMIN} / \mathrm{DF}$ & $0 \leq \mathrm{x}^{2 / \mathrm{sd}} \leq 2$ & $2<x^{2 / s d} \leq 5$ & 2.1010 \\
\hline P değeri & $.05 \leq p \leq 1.00$ & $.01 \leq p \leq .05$ & .00 \\
\hline CFI & $.95 \leq \mathrm{CFI} \leq 1.00$ & $.90 \leq \mathrm{CFI} \leq .95$ & .90 \\
\hline RMSEA & $0 \leq \mathrm{RMSEA} \leq .05$ & $.05<$ RMSEA $\leq .08$ & .06 \\
\hline SRMR & $0 \leq \mathrm{RMR} \leq .05$ & $.05<\mathrm{RMR} \leq .08$ & .05 \\
\hline TLI & $.95 \leq \mathrm{TLI} \leq 1.00$ & $.90 \leq \mathrm{TLI} \leq .95$ & .90 \\
\hline
\end{tabular}

* Hair ve diğerlerinin (2014 s. 584) çalışması referans değerler için temel alınmıştır.

Tablo 4 incelendiğinde SRMR değerlerinin iyi uyum aralığında olduğu, CMIN/df, CFI, RMSEA ve TLI değerlerinin ise kabul edilebilir uyum sınırları dahilinde olduğu bulgulanmıştır.

Modelin kabul edilebilir sınırlar içerisinde olduğu DFA ile bulgulandıktan sonra birleşme geçerliliği incelenmiştir. Birleşme geçerliliğini incelemek için faktör yükleri ve yapı güvenilirliği kontrol edilmektedir. Hair ve diğerleri $(2005$, s. 128) gözlenen değişkenlerin faktör yüklerinin .50 ya da daha yüksek olması gerektiğini belirtmişlerdir. Gözlenen her bir değişkenin kendi gizil değişkeni üzerindeki standart yükü .50 ile .87 arasında farklılaşmaktadır. Bu bağlamda her bir ifadenin, bağlı olduğu boyutta istatistiksel olarak anlamlı yüke sahip olduğu görülmüştür. Diğer bir gösterge ise her bir yapının içsel tutarlılığını gösteren yapı güvenilirliği (CR) değerleridir. Bu değerlerin yanında açıklanan ortalama varyans (AVE) katsayısı üzerinden de ayrıca birleşim geçerliliği kontrol edilebilmektedir. Tablo 5 'te de görüldüğü üzere, (a) faktör yüklerinin uygun aralıkta olduğu (Hair ve diğerleri, 2005, s. 128), (b) CR değerlerinin .7'nin üzerinde olduğu (c) AVE değerinin kabul edilebilir değerlerde olduğu tespit edilmiştir (Fornell ve Larcker, 1981). Fornell ve Larcker'e göre (1981), eğer CR değerleri .6 ve üzerinde ise .4 ve üzerinde hesaplanan AVE değerleri, birleşim geçerliliğinin sağlandığını göstermektedir. Tablo 5 'te ilgili faktör yükleri ve faktörlerin yapı güvenilirliği değerleri (CR) ve açıklanan ortalama varyans (AVE) katsayıları gösterilmiştir. 
Tablo 5. Ölçüm Modelinin Faktör Yükleri, CR ve AVE Katsayıları

\begin{tabular}{|c|c|c|c|c|c|c|c|}
\hline Yapılar/ Değiş̧kenler & $\begin{array}{l}\text { Faktör } \\
\text { Yükleri }\end{array}$ & CR & AVE & $\begin{array}{l}\text { Yapılar/ } \\
\text { Değişkenler }\end{array}$ & $\begin{array}{l}\text { Faktör } \\
\text { Yükleri }\end{array}$ & CR & AVE \\
\hline $\begin{array}{l}\text { Önemsiz Sanal } \\
\text { Kaytarma }\end{array}$ & & .86 & .40 & Yıkıcı Yönetim & & .96 & .65 \\
\hline S9 & 0.50 & & & Y8 & 0.87 & & \\
\hline S8 & 0.65 & & & Y7 & 0.73 & & \\
\hline S7 & 0.76 & & & Y6 & 0.78 & & \\
\hline S6 & 0.52 & & & Y5 & 0.84 & & \\
\hline S4 & 0.64 & & & Y4 & 0.83 & & \\
\hline S3 & 0.79 & & & Y3 & 0.76 & & \\
\hline S2 & 0.73 & & & Y2 & 0.75 & & \\
\hline S1 & 0.67 & & & Y1 & 0.70 & & \\
\hline $\begin{array}{l}\text { Önemli Sanal } \\
\text { Kaytarma }\end{array}$ & & .80 & .48 & İşteki Üretkenlik & & .96 & .64 \\
\hline $\mathrm{S} 18$ & 0.72 & & & U1 & 0.72 & & \\
\hline S17 & 0.66 & & & U2 & 0.70 & & \\
\hline S16 & 0.75 & & & $\mathrm{U} 4$ & 0.78 & & \\
\hline S15 & 0.82 & & & U5 & 0.81 & & \\
\hline S14 & 0.56 & & & U6 & 0.82 & & \\
\hline S13 & 0.78 & & & U7 & 0.77 & & \\
\hline S12 & 0.55 & & & U8 & 0.83 & & \\
\hline S11 & 0.67 & & & U9 & 0.80 & & \\
\hline Yıkıcı Yönetim & & .96 & .65 & U10 & 0.87 & & \\
\hline Y16 & 0.75 & & & U11 & 0.80 & & \\
\hline Y15 & 0.83 & & & U12 & 0.81 & & \\
\hline Y14 & 0.84 & & & U13 & 0.83 & & \\
\hline Y13 & 0.79 & & & U14 & 0.83 & & \\
\hline Y12 & 0.86 & & & U15 & 0.86 & & \\
\hline Y11 & 0.85 & & & U16 & 0.87 & & \\
\hline Y10 & 0.83 & & & U17 & 0.78 & & \\
\hline Y9 & 0.84 & & & U3 & 0.69 & & \\
\hline
\end{tabular}

Yapıların birbirinden bağımsız olması durumu ise ayrışma geçerliliği olarak adlandırılır. Önemli ve önemsiz sanal kaytarma değişkenlerine ait AVE değerlerinin .5'in altında olması nedeniyle ayrışma geçerliliğini sınamak amacıyla ki kare fark testi yapılmıştır (Zaiț ve Bertea, 2011). Yapısal eşitlik modellemesinde değişkenler serbest ve kısıtlanmış olmak üzere iki ayrı model oluşturularak ki kare değerleri izlenmiştir. Her iki model arasındaki ki kare değeri $(2702,79-2325,81)$ 376,98 olarak bulunmuştur $(\Delta \chi(1) 2=376,98, \mathrm{p}<0.05)$. İlgili değerin 3.84 'ten büyük olması nedeniyle her iki boyut arasında ayrışma geçerliliğinin sağlandığı kanaatine varılmıştır (Shiu, Pervan, Bove ve Beatty, 2011). Ek olarak eğer iki gizil değişken arasındaki korelasyon $.90^{\prime}$ dan yüksekse, bu değişkenler arasında çoklu bağlantı olduğu yani değişkenlerin ayrışmadığı sonucu ortaya çıkar (Ghadi, Alwi, Bakar ve Talib 2012, s. 140). İlgili korelasyon değerleri Tablo 6'da gösterilmiştir. Bu tablo sonucunda da ayrışma geçerliliğin sağlandığı görülmektedir.

Tablo 6. Faktör Korelasyon Değerleri

\begin{tabular}{|c|c|c|c|c|}
\hline Faktörler & $\mathbf{1}$ & $\mathbf{2}$ & $\mathbf{3}$ & $\mathbf{4}$ \\
\hline Önemsiz Sanal Kaytarma (1) & 1.00 & & & \\
\hline Önemli Sanal Kaytarma (2) & $0.82^{* *}$ & 1.00 & & \\
\hline Yıkıcı Yönetim (3) & $0.35^{* *}$ & $0.38^{* *}$ & 1.00 & \\
\hline İşteki Üretkenlik (4) & $-0,36^{* *}$ & $-0,41^{* *}$ & $-0,55^{* *}$ & 1.00 \\
\hline
\end{tabular}

** simgesi $\mathrm{p}<.01$ anlamlılık düzeyini göstermektedir.

\section{Yapısal eşitlik modeli}

YEM bir veya daha fazla değişken arasındaki ilişkinin boyutunu incelemektedir ve genellikle birkaç değişkenin ve onlar arasındaki karşılıklı ilişkinin ölçülmesine olanak tanır (Hoe, 2008, s.77). Bu 
çalışma kapsamında da birden fazla değişkenin arasındaki ilişkilerin ölçülmesi ve ölçüm hatalarının elimine edilmesi amacıyla YEM kullanılmıştır.

Yapısal Modelin incelenmesinden önce modelde çoklu doğrusal bağlantı problemi olup olmadığı incelenmiştir. Bağımsız değişkenler arasında güçlü ilişkiler olmasına bağlantı ya da çoklu doğrusal bağlantı adı verilmektedir (Orhunbilge, 2000). Bu çalışma kapsamında çoklu doğrusal bağlantının saptanmasında varyans arttırıcı faktör (VIF) kullanılmıştır (Albayrak, 2005, s.110). Bilgisayar yazılımından alınan sonuçlara göre VIF'ler hesaplanmıştır. Bu bağlamda yıkıcı yönetim değişkeninin VIF'1 1.179, önemli sanal kaytarmanın 3.310 ve önemsiz sanal kaytarmanın 3.209 olarak hesaplanmıştır. Hair ve diğerleri $(2019$, s.10)'nin yaptığı çalışmada, VIF < 5 ise modelde herhangi bir doğrusallık probleminin olmadığı belirtilmiştir. Bu bağlamda bilgisayar yazılımından elde edilen sonuçlar neticesinde modelin doğrusallık probleminin olmadığı bulgulanmıştır.

Yapısal model bilgisayar yazılımı ile test edildikten sonra, öncelikle parametrelerde, Hair ve diğerlerinin $(2005$, s. 796) önerisi doğrultusunda kabul edilebilir kriterleri sağlamayan tahminlerin olup olmadığı incelenmiş ve herhangi bir kabul edilebilir kriterleri sağlamayan tahmin olmadığ1 görülmüştür. Akabinde, modelin uyum iyiliği ölçütlerinin referanslarla karşılaştırılması bölümüne geçilmiştir.

Yapısal eşitlik modellemesinde de ölçüm modelinde referans alınan uyum iyiliği ölçütlerinden yararlanılmıştır. Yapısal eşitlik modellemesi sonrasında, ortaya çıkan uyum ölçütleri referans değerlerle karşılaştırılmış ve modifikasyon indeksleri kontrol edilmiştir. İndeks değerlerinin en yükseklerinin içsel değişkenler olan önemsiz sanal kaytarma ve önemli sanal kaytarma olduğu görülmüştür. İlgili modifikasyon gerçekleştirildiğinde, ölçütler kabul uyum seviyelerine ulaşmıştır. Tablo 7'de yer alan uyum iyiliği ölçütlerinin referans değerleri ile ilgili olarak ölçüm modelinde olduğu gibi Hair ve diğerleri (2014 s. 584) temel alınmıştır.

Tablo 7. YEM Uyum İyiliği Sonuçları

\begin{tabular}{|c|c|c|c|}
\hline \multirow{2}{*}{$\begin{array}{c}\text { Uyum İyiliği } \\
\text { Ölçütleri }\end{array}$} & \multicolumn{2}{|c|}{ Referans Değerler } & \multirow{2}{*}{$\begin{array}{c}\text { Öçüm Modeli } \\
\text { Sonuçları }\end{array}$} \\
\cline { 2 - 3 } & İyi Uyum & Kabul Edilebilir Uyum & 1106 \\
\hline $\mathrm{DF}(\mathrm{sd})$ & - & - & 2319.66 \\
\hline $\mathrm{CMIN}(\mathrm{x} 2)$ & $0 \leq \mathrm{x}^{2} \leq 2 \mathrm{sd}$ & $2 \mathrm{sd} \leq \mathrm{x}^{2} \leq 3 \mathrm{sd}$ & 2.0974 \\
\hline $\mathrm{CMIN} / \mathrm{DF}$ & $0 \leq \mathrm{x}^{2 / \mathrm{sd}} \leq 2$ & $2<\mathrm{x}^{2 / \mathrm{sd}} \leq 5$ & .00 \\
\hline $\mathrm{P}$ değeri & $.05 \leq \mathrm{p} \leq 1.00$ & $.01 \leq \mathrm{p} \leq .05$ & .90 \\
\hline $\mathrm{CFI}$ & $.95 \leq \mathrm{CFI} \leq 1.00$ & $.90 \leq \mathrm{CFI} \leq .95$ & .06 \\
\hline RMSEA & $0 \leq \mathrm{RMSEA} \leq .05$ & $.05<\mathrm{RMSEA} \leq .08$ & .05 \\
\hline SRMR & $0 \leq \mathrm{RMR} \leq .05$ & $.05<\mathrm{RMR} \leq .08$ & .90 \\
\hline TLI & $.95 \leq \mathrm{TLI} \leq 1.00$ & $.90 \leq \mathrm{TLI} \leq .95$ & \\
\hline
\end{tabular}

* Hair ve diğerlerinin (2014 s. 584) çalışması referans değerler için temel alınmıştır.

Tablo 7'deki sonuçlara istinaden, modelin $\mathrm{p}$ değeri anlamlıdır $(p<.00)$. Ancak geleneksel anlamlılık testinin tersine $x^{2}$ testinde anlamsız bir $\mathrm{p}$ değeri elde edilmek istenir (Sümer, 2000). Dolayısıyla istenen $\mathrm{x}^{2}$ beklenen anlamlılık seviyesi $\mathrm{p}>.05^{\prime}$ dir (anlamlı olmaması). YEM'de ki-kare değerinin anlamlı çıkmaması modelin uyumunu göstermektedir. Ancak, Hair ve diğerlerine (2010) göre ki-kare değerinin; örneklem büyüklüğü, parametre sayısı, dağılım gibi farklı faktörlerden etkilenme olasılığı nedeni ile tek başına değerlendirilmemesi gerekmektedir. Çünkü aksi takdirde Tip I (doğru olduğu halde hipotezi reddetme olasılığı) ve Tip II (yanlış olduğu halde hipotezi kabul etme olasılığı) hataları ile karşılaşılabilir. Bu sebeple diğer uyum indeksleri de dikkate alınmalıdır. Hu ve Bentler (1999) de aynı kapsamda uyum indekslerini değerlendirdikleri çalışmalarında SRMR değeriyle birlikte TLI veya CFI değerlerinin verilmesini önermektedirler. YEM uyum iyiliği sonuçların değerlendirildiğinde; CMIN/df, TLI, CFI, RMSEA ve değerleri kabul edilebilir seviyelerde olup SRMR değeri iyi uyum aralığındadır. Dolayısıyla verilerin kurulan modele uyum gösterdiği görülmektedir.

Hair ve diğerleri $(2005$, s. 862$)$ yapısal modele ilişkin analizlerde model uyum indekslerinin yanı sıra doğrulayıcı faktör analizi ve yapısal eşitlik modellemesi sonucunda hesaplanan faktör yüklerinin de karşılaştırılması gerektiğini belirtmişlerdir. Bunun nedeni, faktör yüklerinin karşılaştırılmasının sonucunda parametrelerin sabitliğinin görülmesi ve modelin geçerliliğinin desteklenmesidir. Yapısal modeldeki faktör yükleri ve doğrulayıcı faktör analizi sonuçları arasında önemli bir ayrışma görülmemiş̧tir. Dolayısıyla modelin geçerliliği desteklenmektedir. 
Modele ilişkin uyum iyiliği sonuçlarının kabul edilebilir seviyelerde olduğu görüldükten sonra, hipotezlerde yer alan gizil değişkenler arasındaki ilişkilerin gücünün ve yönünün incelenmesini aşamasına geçilmiştir. Bu süreçte, öncelikle araştırma modelindeki yol katsayıları bilgisayar yazılım programı üzerinden hesaplanmıştır. Değişkenler arasındaki ilişkiler açıklanırken $R^{2}$ değerinin, gözlemlenen değişkenlerin çoklu korelasyon katsayılarının karelerini ifade ettiğini vurgulamak gerektir. Yani $\mathrm{R}^{2}$ değeri; belirli sayıdaki değişkenin, üzerinde etkili oldukları başka bir değişkeni ne kadar iyi ölçtügünü ortaya koyar.

Araştırma sonuçlarından elde edilen bulgulara göre yıkıcı yönetimin $(-0.44, p<.001)$ işteki üretkenlik üzerinde istatistiksel olarak anlamlı etkiye sahip olduğu ve etkinin yönünün negatif olduğu izlenmektedir. Önemsiz $(\mathrm{p}>.10)$ ve önemli sanal kaytarmanın ise $(\mathrm{p}>.10)$ işteki üretkenlik üzerindeki etkilerinin istatistiksel olarak anlamlı olmadığı görülmüştür. Bu bağlamda önemsiz ve önemli sanal kaytarma olarak iki boyutta ele alınan sanal kaytarma davranışı boyutları ile yıkıcı yönetimin, toplam olarak işteki üretkenlikteki değişimin \%38'ini açıklayabildikleri görülmüştür. Yıkıcı yönetimin her iki sanal kaytarma davranışı boyutunu da pozitif yönde etkilediği izlenmektedir. Detaylandırılacak olursa, yıkıcı yönetimin önemsiz sanal kaytarma üzerinde $(0.37, p<.001)$ istatistiksel olarak anlamlı etkiye sahip olduğu ve önemsiz sanal kaytarma üzerindeki değişimin \%14'ünü açıkladığı bulgulanmıştır. Yıkıcı yönetimin önemli sanal kaytarma üzerinde $(0.41, p<.001)$ istatistiksel olarak anlamlı etkiye sahip olduğu ve önemli sanal kaytarma üzerindeki değişimin \%17'sini açıkladığı görülmüştür. Önerilen hipotezlerin test sonuçlarına göre $\mathrm{H}_{1}, \mathrm{H}_{2}$ ve $\mathrm{H}_{3}$ ün desteklendiği; $\mathrm{H}_{4}$ ve $\mathrm{H}_{5}$ 'in ise desteklenmediği görülmektedir. Bulgular ile ilgili detaylı bilgiler sonuç kısminda ele alınmıştır.

\section{Sonuç ve değerlendirme}

\section{Araştırmanın sonuçları}

Araştırma kapsamında önerilen hipotezlerin test sonuçlarına göre, beş hipotezden üçünün desteklendiği, ikisinin ise desteklenmediği görülmektedir. $\mathrm{H}_{1}$ ve $\mathrm{H}_{2}$ değerlendirildiğinde; yıkıc1 yönetimin, hem önemli hem de önemsiz sanal kaytarma davranışlarının üzerinde anlamlı ve pozitif yönlü etkili olduğu gözlemlenmektedir. Diğer bir ifadeyle, yıkıcı yönetimin artması sanal kaytarma davranışlarının iki boyutunda da artışa, azalması ise sanal kaytarma davranışlarının iki boyutunda da düşüşe neden olmaktadır.

Literatür incelemesi yapıldı̆̆ında, yıkıcı yönetimin sanal kaytarma davranışlarını pozitif yönde etkilediği bulgulanmıştır (Ezeh, Etodike ve Chukwura, 2018). Başka bir deyişle yıkıcı yönetim arttı̆̆ında sanal kaytarma davranışlarının da arttığı görülmüş̧tür. Yapılan çalışmalarda yıkıcı yönetim algılayan çalışanların sadece işe, örgüte ve sosyal yaşama yönelik tutumları olumsuz etkilenmemekte aynı zamanda bu çalışanların örgütsel işleyişe zarar verme eğilimlerinin de arttığı bulgulanmıştır (Martinko ve diğerleri, 2013; Robinson ve Bennet, 1995). Çalışanlarda yıkıcı yönetim algısı veya olumsuz çalışma koşullarına (Davis-Blake ve diğerleri, 2003) bağlı olarak psikolojik sözleşmenin tahribatı sonucu, iş doyumsuzluğu (Turnley ve Feldman 1999), iş güvencesizliği (Sezici ve Güven, 2017) ve üretkenlik karşıtı iş yeri davranışlarından olan sanal kaytarma davranışlarının (Yıldız H., Yıldız, B., ve İyigün, 2006) da ortaya çıktığı bulgulanmıştır.

Wang ve diğerleri (2012)'nin yaptıkları çalışmada yıkıcı yönetime maruz kalan çalışanların onurlarını ve haysiyetlerini korumak adına, yıkıcı yöneticilere kişisel olarak tepki gösterme eğiliminde oldukları ve bilinçli olarak sapkın davranışlar sergileyerek yöneticilerinden adeta intikam almak için çaba sarf ettikleri bulgulanmıştır. Chiu ve Peng (2008) yıkıcı yönetim algısının oluştuğu durumlarda kişinin sapkınlığa ve üretkenlik karşıtı davranışlara daha yatkın olduğunu bulgulamışlardır. Dolayısıyla, yönetimin sanal kaytarmayı anlamlı ve pozitif yönlü etkilemesi bulgusunun literatürdeki çalışmalara paralel olduğu görülmüştür.

Genel itibari ile yıkıcı yönetimin çalışanlarda hem fiziksel hem psikolojik olumsuz etkilere yol açması, stresi artırması, motivasyonu düşürmesi gibi sonuçları göz önüne alındığında, çalışanların sanal kaytarma davranışına yönelmeleri olağan karşılanabilir. Çalışanlar; öç alma, zarar verme, iş yapmama gibi olumsuz amaçlarla önemli sanal kaytarma davranışlarına yönelebileceği gibi, iş ortamından uzaklaşma, stresten arınma ve kendini daha iyi hissetmek için de mesai saatleri içerisinde önemsiz sanal kaytarma davranışlarında bulunarak vakit geçirebilirler. Nitekim bu çalışma sonuçlarında literatüre benzer olarak yıkıcı yönetimin sanal kaytarma davranışlarını artırdığı bulgulanmıştır.

Araştırmada ele alınan üçüncü hipotez olan yıkıcı yönetimin işteki üretkenliği negatif yönde etkilediği varsayımı da desteklenmiştir. Yıkıcı yönetim ve işteki üretkenlik arasında anlamlı ve negatif yönlü bir etki olduğu bulgulanmıştır. Bu bağlamda, yıkıcı yönetim algısı arttıkça işteki üretkenlikte düşüş 
gözlemlenmektedir. Literatür incelemesi yapıldığında bu bulgunun genel olarak yapılan çalışmalarla paralel olduğu izlenmiştir. Yıkıcı yönetim sonucunda üretkenliğin dolaylı veya doğrudan etkilendiği birçok çalışmada bulgulanmıştır (Chiu ve Peng, 2008; Davis-Blake ve diğerleri, 2003; Jones, 2009; Martinko ve diğerleri, 2013; Özsoy ve Serdar, 2019; Robinson ve Bennet, 1995; Turnley ve Feldman 1999: 907). Bir çalışmada da yıkıcı liderlik davranışlarının çalışanların sadakatlerini azalttığı ve üretkenlik karşıtı iş davranışları sergileme eğilimini arttırdığı vurgulanmıştır (Harris, Kacmar ve Zivnuska, 2007).

Gündüz ve Dedekorkut (2014)'un çalışmasında ise yıkıcı yönetimin, çalışanların işlerine ve örgütlerine yönelik negatif algılamalara yol açtığı, motivasyonu ve performansı düşürdüğü, sadakati azalttığı, kişileri üretkenlik karşıtı davranışlara yönelttiği belirtilmiştir. Benzer olarak Bassman ve London (1993)'ın yaptıkları çalışmada da yıkıcı yönetimin çalışanlar üzerinde yüksek düzeyde negatif etkisi olduğu ve çalışanlarda oluşan işe yabancılaşma ve artan stres sonucu çalışanların performanslarında, organizasyonlarına bağlılıklarında ve kariyer motivasyonlarında düşüşlere yol açtığı bulgulanmıştır.

Yıkıcı yönetime maruz kalan çalışanlar farklı tepkiler vermeyi tercih edebilirler. Bazıları durumu kabullenip içine kapanarak çalışmaya devam etmekte, bazı çalışanlar tepki göstererek işleri askıya almakta, bazıları ise yeni iş arayışlarına girmektedirler. Çalışanların olası tepkilerindeki ortak yön, yıkıcı yönetimin sonuçlarından örgütün ve/veya çalışanın zarar görmesidir. Benzer olarak, bu çalışma sonucunda da yıkıcı yönetimin işteki üretkenliği negatif yönde etkilediği hipotezi desteklenmiş olup, bu sonucun literatürdeki çalışmalarla benzerlik taşıdığı görülmüştür.

Araştırmadaki son iki hipotez ise sanal kaytarma davranışı boyutlarının işteki üretkenliği negatif yönlü etkilediği varsayımı çerçevesinde oluşturulmuştur. Analiz sonuçlarına göre sanal kaytarma davranışının her iki boyutunun da işteki üretkenlik üzerindeki etkilerinin anlamlı olmadığı bulgulanmıştır. Dolayısıyla önemsiz ve önemli sanal kaytarma davranışlarının işteki üretkenliği negatif yönde etkilemesine yönelik kurulan hipotezler desteklenmemiştir.

Mashal (2017)'ın yaptığı çalışmada da sanal kaytarmanın işteki üretkenlik üzerindeki etkisinin anlamlı olmadığı sonucuna varılmıştır. Literatürde yer alan çalışmalarda da sanal kaytarmanın işteki üretkenliğe etkisi hakkında net bir fikir birliğine varılamamış olduğu görülmektedir. Sanal kaytarmanın işteki üretkenliğe sıklıkla olumsuz etki ettiğine yönelik çalışmalar olmasına rağmen (Buyruk Akbaba, 2019; Demir ve diğerleri, 2017; Giordano ve Dilchert, 2017; Hussain ve Parida, 2017; Jiang, 2020; Kuschnaroff ve Bayma, 2014; Lim ve diğerleri, 2002; Mercado, Shaddiq, Haryono, Muafi ve Isfianadewi, 2021), olumlu etkilediğini belirten çalışmalar da bulunmaktadır (Blanchard ve Henle, 2008; Keklik, Kılıç, Yıldız H., ve Yıldız, B., 2015; Koay ve Soh, ,2018; Saleh, Daqqa, Abdulrahim, ve Sakallah, 2018; Sao, Chandak, Patel ve Bhadade, 2020; Weissenfeld, Abramova ve Krasnova, 2019). Bu bağlamda, banka çalışanlarının sanal kaytarma yaptıkları zamanlarda sanal kaytarmanın bütünüyle olumsuz sonuçları ile karşılaşmadıkları, aksine iş ortamından uzaklaşma, zihinsel olarak dinlenme, bilgi edinme, yetenek ve yaratıcılıklarını geliştirme gibi olumlu sonuçlarından da faydalandıkları söylenebilir. Bu sebeple üretkenliklerinde bir denge sağlamaları durumu söz konusu olabilir. Bu bağlamda, bu çalışma çerçevesinde sanal kaytarmanın işteki üretkenlikle olan ilişkisinde nötr bir kavram olarak ele alınabileceği bulgulanmıştır.

Sanal kaytarma ve işteki üretkenlik arasındaki ilişkinin anlamlı çıkmamasının bir diğer sebebinin de sosyal beğenirlik etkisi ile alakalı olduğu düşünülmektedir. Gerçekte gerçekleştirilen eylemleri gizleme davranışlarını açıklamaya çalışan kavramlardan biri olan sosyal beğenirlik, katılımcıların yapılan araştırmalarda kendilerini sosyal normlara uygun bir birey olarak yansıtma eğilimi olarak açıklanabilir (King ve Bruner, 2000, s. 81). Sanal kaytarma davranışları mesai saatleri içerisinde iş dışı faaliyetler ile ilgilenilmesini kapsamaktadır. Bu faaliyetlerin içerisinde internetteki sanal toplulukları ziyaret etme, kumar veya bahis oynama gibi eylemler de bulunmaktadır. Söz konusu eylemler, sosyal normlara çok da uygun olmayan, daha ziyade gizli gerçekleştirilmek istenen ve sosyal ortamlarda ifade edilmesinden imtina edilecek eylemler olarak özetlenebilir. Bu ve bunun gibi hassas konuların incelenmesine yönelik yapılan çalışmalarda temin edilen verilere, araştırmacılar dışındaki kişilerce (aile, arkadaşlar, yöneticiler, kanun koyucular vb.) ulaşılması, çalışmaya katılanların maddi ve manevi zarar görmelerine sebep olabilmektedir (Singer, 2004, s. 32). Özellikle Türkiye gibi kişiler arası güvenin oldukça düşük düzeyde olduğu toplumlarda (Aslan, 2016, s. 191) zarar görme riski daha da yüksek seviyede algılanabilir. Dolayısıyla, çalışanların sanal kaytarma yaptıklarını net bir şekilde ifade etmekten imtina edebilecekleri (Yıldız, H., Yıldız, B., ve Ateş, 2014) dikkate alınarak, sosyal beğenirliğe yönelik kaygılar sonuçlar üzerinde etkili olmuş olabilir.

Kuramsal açıdan bakıldığında bu çalışma, Blau'nun (1964) Sosyal Mübadele Teorisi çerçevesinde değerlendirilebilir. Sosyal mübadele teorisinin karşılıklılık ilkesi gereği yıkıcı yönetimin, yöneticiler ve 
çalışanlar arasındaki karşılıklı etkileşimin kalitesini düşürmesi beklenmektedir (Tepper, 2000). Bu bağlamda yıkıcı yönetimin olumsuz etkilerini gösteren birçok çalışmanın bu teori çerçevesinde ele alındığı görülmüsştür (Örneğin; Choi, Kim ve Yun, 2019; Guo, Zhao, Cheng ve Luo, 2020; Kim, Kim ve Yun, 2015; Mackey, McAllister, Brees, Huang ve Carson, 2018; Tepper, 2000; Valle, Kacmar, Zivnuska ve Harting, 2019).

Sosyal Mübadele Teorisi perspektifiyle bakıldığında yöneticinin arzu edilmeyen davranışlarının, çalışanların misilleme davranışlarını arttırdığı (Mitchell and Ambrose, 2007, Skarlicki and Folger, 1997) ve bu durumda da çalışanların öç alma veya zarar verme çabası içine girdikleri belirtilmiştir (Skarlicki ve Folger, 2004). Bu çalışmada desteklenen hipotezler de bu duruma işaret etmektedir. Dolayısıyla bu teori kapsamında, yıkıcı yönetime maruz kalan çalışanların bu çalışma sonuçları ile benzer olarak sapkın davranışlara yönelmesi ve/veya işteki üretkenliklerinin de negatif yönde etkilenmesi olağan karşılanabilir.

\section{Araştırmanın sınırlılıkları}

Her araştırmada görüldüğü gibi bu çalışmada da birtakım sınırlılıklar bulunmaktadır. İşteki üretkenliğin; stres, örgütsel bağlllık, örgütsel adalet, kişilik gibi pek çok faktör tarafından etkilendiği literatürde gözlemlenmiştir. Bu araştırma kapsamında, işteki üretkenliğin öncülleri olarak sanal kaytarma davranışı ve yıkıcı yönetim ele alınmış, işteki üretkenlik üzerinde etkili olabilecek potansiyel diğer yordayıcılar kapsam dışında bırakılmıştır. Bu durum, araştırmanın temel sınırlılığı olarak değerlendirilebilir. Yapılan literatür incelemesinde, araştırma modelinde yer alan kavramların ikili ilişkilerini inceleyen araştırmalar gözlenmiş ancak bu üç kavramı bir arada inceleyen herhangi bir araştırma ile karşılaşılmamıştır. Çalışma konusu ile alakalı araştırmaların sınırlı olması, araştırma sonuçlarının farklı çalışma sonuçları ile karşılaştırılmasını ve araştırmaların benzeyen ya da ayrışan yönlerinin tartışılmasını engelleyebilir. Araştırmanın tek bir sektörde ve tek bir ili kapsayan sınırlı bir örneklemle gerçekleştirilmesi de bir sınırlılık olarak görülebilir. Yapılan analizler sonucu elde edilen sonuçların farklı örneklemlerde değişebileceği göz önüne alındığında, sonuçların verilerin toplandığı örneklem ile sinırlı olduğu belirtilmelidir.

\section{Uygulayıcılara ve araştırmacılara yönelik öneriler}

Bu çalışma sonuçlarına bağlı olarak, işletmelerdeki yöneticilere yıkıcı yönetimin olası zararlarına yönelik bilgilendirici eğitimler verilerek yıkıcı yönetim uygulamalarının önüne geçilmesi önerilmektedir. İlaveten işletmeler sanal kaytarma davranışlarına yönelik güvenlik açığı oluşturmayacak şekilde kısmi esneklikte bir kısıtlama politikası uygulayabilir (Holguin, 2016; Jandaghi, Alvani, Zarei Matin ve Fakheri 2015; Piotrowski, 2012; Rahimnia ve Mazidi, 2015) ve üretkenlik için tehdit olarak gördükleri spesifik sanal kaytarma davranışlarını takip ederek gerektiğinde ilave önlemler alabilirler.

Çalışma sonuçlarına bağlı olarak araştırmacılara ise şu öneriler getirilmiştir. Sanal kaytarma davranışlarını inceleyen sınırlı sayıda araştırma olduğu görülmüş̧ür, bu bağlamda kavramı içeren çalışmalar yapılması gerektiği düşünülmektedir. Bu çalışma kapsamındaki katılımcıların, sorulan soruları gerçek durum yerine, olması gereken duruma göre veya sosyal beğenirlik etkisi altında cevaplandırmış olabileceği değerlendirilmektedir. Sanal kaytarma kavramında olduğu gibi hassas konuları içeren çalışmalarda temin edilen verilerin ve veri toplama araçlarının geçerliği tehlikeye atabildiği göz önünde bulundurulduğunda, çalışmalarda sosyal beğenirlik etkisinin de ayrıca ölçülmesinin faydalı olabileceği değerlendirilmektedir (Merydith, Plout ve Blaha, 2003; Miller, 2012). Ek olarak, bu çalışmada yer alan değişkenlerin aracı veya düzenleyici rolleri de incelenebilir. Bu çalışma tek bir bölgede ve kısıtlı bir örneklemle yapılmıştır. Analiz sonuçlarının farklı örneklemlerde değişebileceği göz önüne alındığında, sonuçların verilerin toplandığı örneklem ile sınırlı olduğu belirtilmelidir. Bu sebeple daha geniş bir örneklemle çeşitli sektör çalışanlarının katılımları sağlanarak değişkenler arası ilişkiler incelenebilir. Ayrıca COVID-19 sürecinde işyerinde çalışmanın yanı sıra dönüşümlü olarak evden de çalışmaya başlanılması ile birlikte mesai saatlerinin daha esnek hale geldiği görülmektedir. Bu durumun da sanal kaytarma faaliyetlerini değerlendirmeyi zorlaştıracağı düşünülmektedir. Çünkü mesai saatlerinin esnek hale gelmesi ile iş-yaşam dengesi arasındaki çizgi bulanık hale gelerek sanal kaytarma kavramının temel öğelerini belirsiz hale getirmiştir. Bu sebeple bu süreçte yapılacak olan sanal kaytarma davranışlarına yönelik çalışmalarda, bu durum bir kısıt olarak değerlendirilmelidir. 


\section{Hakem Değerlendirmesi / Peer-review:}

Dış bağımsız

Externally peer-reviewed

\section{Çıkar Çatışması / Conflict of interests:}

Yazar(lar) çıkar çatışması bildirmemiştir.

The author(s) has (have) no conflict of interest to declare.

\section{Finansal Destek / Grant Support:}

Yazar bu çalışma için finansal destek almadı̆̆ını beyan etmiştir.

The author declared that this study has received no financial support.

\section{Kaynakça / References}

Achakul, C. ve Yolles, M. (2013). Intrinsic and extrinsic motivation in personality: Assessing knowledge profiling and the work preference inventory in a Thai population. Journal of Organisational Transformation \& Social Change, 10(3), 196-217.

Akgeyik, T., Güngör, M., Uşen Ş. ve Omay, U. (2007). İş yerinde psikolojik taciz fenomeni: Uluslararası deneyimler ve perspektifler. Sosyal Siyaset Konferansları Dergisi, 53, 232-254.

Albayrak, A. S. (2005). Çoklu doğrusal bağlantı halinde en küçük kareler tekniğinin alternatifi yanlı tahmin teknikleri ve bir uygulama. Uluslararası Yönetim İktisat ve İşletme Dergisi, 1(1), 105-126.

Anandarajan, M., Paravastu, N. ve Simmers, C. A. (2006). Perceptions of personal web usage in the workplace: AQ-methodology approach. CyberPsychology E Behavior, 9(3), 325-335.

Aryee, S., Chen, Z. X., Sun, L.-Y. ve Debrah, Y. A. (2007). Antecedents and outcomes of abusive supervision: test of a trickle-down model. Journal of Applied Psychology, 92(1), 191-201.

Aslan, S. (2016). Türkiye'de sosyal sermaye bileşenlerinden güven hakkında bir değerlendirme. Cumhuriyet Üniversitesi İktisadi ve İdari Bilimler Dergisi, 17(2), 181-204.

Bassman, E. ve London, M., (1993) Abusive Managerial Behaviour, Leadership E Organization Development Journal, 14(2), 18-24.

Bollen, K. A. (2005). Structural equation models. Encyclopedia of biostatistics. (7.bs.) New York: John Wiles \& Sons.

Blanchard, A. L. ve Henle, C. A. (2008). Correlates of different forms of cyberloafing: The role of norms and external locus of control. Computers in Human Behavior, 24(3), 1067-1084.

Blau, P.M. (1964). Social Exchange Theory. New York. John Wiley \& Sons.

Buyruk Akbaba, A. N. (2019). Effects of cyberloafing on productivity and Cost: a field study. Verimlilik Dergisi, 3, 161-179.

Buyruk, H. (2018). Gelişen Teknolojiler, Değişen İşgücü Nitelikleri ve Eğitim. OPUS-Uluslararası Toplum Araştırmaları Dergisi, 8(14), 599-632.

Büyüköztürk, Ş., Kılıç Çakmak, E., Akgün, Ö. E., Karadeniz, Ş. ve Demirel, F. (2014). Bilimsel araştırmanın temelleri (9. bs.). Ankara: Pegem Akademi.

Camus, D. (2007). Publishing productivity measures in ONS. Economic \& Labour Market Review, 1(7), 19-21.

Candan, H. ve İnce, M. (2016). A research on the relationship between cyberloafing and organisational 
commitment of police department personnel. Niğde University Journal of Economics \& Administrative Sciences, 9(1), 229-235.

Chiu, S.F. ve Peng J.C. (2008). The relationship between psychological contract breach and employee deviance: the moderating role of hostile attributional style Journal of Vocational Behaviour, 73 (3), $426-433$.

Choi, W., Kim, S. L. ve Yun, S. (2019). A social exchange perspective of abusive supervision and knowledge sharing: Investigating the moderating effects of psychological contract fulfillment and self-enhancement motive. Journal of Business and Psychology, 34(3), 305-319.

Churchill Jr, G. A. (1979). A paradigm for developing better measures of marketing constructs. Journal of Marketing Research, 16(1), 64-73.

Coker, B. L. (2011). Freedom to surf: The positive effects of workplace Internet leisure browsing. New Technology, Work and Employment, 26(3), 238-247.

Cropanzano, R. ve Mitchell, M. S. (2005). Social exchange theory: An interdisciplinary review. Journal of Management, 31(6), 874-900.

Çokluk, Ö., Şekercioğlu, G. ve Büyüköztürk, Ş. (2010). Multivariate statistics for the social sciences: SPSS and LISREL applications. Ankara: Pegem Akademi.

Davis-Blake, A., Broschak, J. P. ve George, E. (2003). Happy together? How using nonstandard workers affects exit, voice, and loyalty among standard employees. Academy of Management Journal, 46(4), 475-485.

Demir B., I., Ürek, D. ve Uğurluoğlu, Ö. (2017). Sağlık Çalışanlarının Sanal Kaytarma Davranışlarının İşte Üretkenliklerine Etkisi. AJIT-e: Online Academic Journal of Information Technology, 8(30), 291 -303.

Endicott, J. ve Nee, J. (1997). Endicott Work Productivity Scale (EWPS): a new measure to assess treatment effects. Psychopharmacology Bulletin, 33(1), 13.

Ergül, H. (1999). Uzaktan Öğretimde Kalite Verimlilik ve Üretkenlik. Kurgu Dergisi, 16, 283-296.

Ertürk, E.(2014). Sosyal mübadele teorisi bağlamında güç mesafesi ve örgütsel adalet algılamalarmın örgütsel vatandaşlık davranışı üzerindeki etkisi (Doktora Tezi) Ulusal Tez Merkezi'nden erişildi. (Tez No: 377783.).

Ezeh, L. N. Etodike, C. E. ve Chukwura, E. N. (2018). Abusive supervision and organisational cynicism as predictors of cyber-loafing among federal civil service employees in Anambra state, Nigeria. European Journal of Human Resource Management Studies, 1(2), 19-36.

Fornell C. ve D. F. Larcker. (1981). Evaluating structural equation models with unobservable variables and measurement error. Journal of marketing research, 39-50, 1981.

Johnson, R. A. ve Wichern, D. W. (2002). Applied Multivariate Statistical Analysis, (5.bs.). New Jersey: Prentice Hall.

Ghadi, I., Alwi N.H., Bakar K.A. ve Talib O. (2012). Construct Validity Examination of Critical Thinking Dispositions for Undergraduate Students in University Putra Malaysia. Higher Education Studies, 2(2), 138-145.

Gouldner, A. W. (1960). The norm of reciprocity: A preliminary statement. American Sociological Review, 25(2), 161-178.

Guo, L., Zhao, H., Cheng, K. ve Luo, J. (2020). The relationship between abusive supervision and unethical pro-organisational behavior: linear or curvilinear?. Leadership \& Organization Development Journal. 369-381.

Gündüz, Y. ve Dedekorkut, S. E. (2014). Yıkıcı Liderlik. Mersin University Journal of the Faculty of Education, 10(1), 95-104.

Hair, J. F., Risher, J. J., Sarstedt, M. ve Ringle, C. M. (2019). When to use and how to report the results of PLS-SEM. European Business Review.2-24.

Hair, J. F., Black, W. C., Babin, B. J., Anderson, R. E. ve Tatham, R. L. (2005). Multivariate Data Analysis. New Jersey: Pearson Prentice Hall.

Hair, J. F., Black, W. C., Babin, B. J., Anderson, R. E. ve Tatham, R. L. (2010). SEM: An introduction. Multivariate data analysis: A global perspective.. New Jersey: Pearson Prentice Hall. 
Hair, J. F., Black, W. C., Babin, B. J. ve Anderson, R. E. (2014). Multivariate data analysis: Pearson new international edition. Essex: Pearson Education Limited, 1, 2.

Harris, K. J., Kacmar, K. M. ve Zivnuska, S. (2007). An investigation of abusive supervision as a predictor of performance and the meaning of work as a moderator of the relationship. The Leadership Quarterly, 18(3), 252-263.

Harvey, S., ve Keashly, L. (2003). Predicting the risk for aggression in the workplace: Risk factors, selfesteem and time at work. Social Behavior and Personality: an international journal, 31(8), 807-814.

Hoe, S.L. (2008). Issues and procedures in adopting structural equation modeling technique. Journal of Applied Quantitative Methods, 3(1), 76-83.

Holguin, E. S. (2016). Strategies functional managers use to control cyberloafing behaviors (Doktora Tezi, Walden University, Minnesota). Erişim Adresi: http://scholarworks.waldenu.edu/dissertations. (UMI No. 10141379)

Hoyle R.H. (1995). Structural Equation Modeling: Concepts, Issues, and Applications. Thousand Oaks, CA: Sage Publications.

Hu, L. ve Bentler, P. M. (1999). Cutoff criteria for fit indexes in covariance structure analysis: Coventional criteria versus new alternatives, Structural Equation Modeling, 6(1), 1-55.

Hussain, S. ve Parida, T. (2017). Exploring cyberloafing behavior in South-central Ethiopia: A close look at Madda Walabu University. Journal of Media and Communication Studies, 9(2), 10-16.

Jandaghi, G., Alvani, S. M., Zarei Matin, H. ve Fakheri Kozekanan, S. (2015). Cyberloafing management in organisations. Iranian Journal of Management Studies, 8(3), 335-349.

Jiang, H. (2020). Understanding the Mental Recovery Effect of Cyberloafing: Attention Replenishment and Task-Set Inertia. Cham: Springer.

Jones, D. A. (2009). Getting even with one's supervisor and one's organisation: Relationships among types of injustice, desires for revenge, and counterproductive work behaviors. Journal of Organizational Behavior: The International Journal of Industrial, Occupational and Organisational Psychology and Behavior, 30(4), 525-542.

Kalaycı, Ş. (2010). SPSS uygulamalı çok değişkenli istatistik teknikleri (5.bs.) Ankara: Asil Yayın Dağıtım.

Kaplan, M. ve Çetinkaya, A. (2014). Sanal Kaytarma ve Demografik Özellikler Açısından Farklılıklar: Otel İşletmelerinde Bir Araştırma. Anatolia: Turizm Araştırmaları Dergisi, 25 (1), 26-34.

Kaplan, M. ve Öğüt, A. (2012). Algılanan Örgütsel Adalet İle Sanal Kaytarma Arasindaki İlişkinin Analizi: Hastane Çalışanları Örneği. Dokuz Eylül Üniversitesi İşletme Fakültesi Dergisi, 13(1), 1-13.

Keklik, B., Kılıç, R., Yıldız, H. ve Yıldız, B. (2015), Sanal kaytarma davranışlarının örgütsel öğrenme kapasitesi üzerindeki etkisinin incelenmesi, Business and Economics Research Journal, 6(3), 129-144.

Kim, S. L., Kim, M. ve Yun, S. (2015). Knowledge sharing, abusive supervision, and support: A social exchange perspective. Group E Organization Management, 40(5), 599-624.

King, M. F., ve Bruner, G. C. (2000). Social desirability bias: A neglected aspect of validity testing. Psychology \& Marketing, 17(2), 79-103.

Klotz, A. C. ve Buckley, M. R. (2013). A historical perspective of counterproductive work behavior targeting the organisation. Journal of Management History, 19(1), 114-132.

Koay, K. Y. ve Soh, P. C. H. (2018). Does cyberloafing really harm employees' work performance?: An overview. Cham: Springer.

Kobu, B., 1987. Üretim Yönetimi. İ.Ü. İşletme Fakültesi Yayın No: 181, İstanbul.

Kurt, M. (2011, Eylül) Siber Aylaklık Davranışlarının Karşılaştırmalı Olarak İncelenmesi. Fırat Universitesi 5th International Computer \& Instructional Technologies Symposium, Elazı̆̆.

Kuschnaroff, F. ve Bayma, F. (2014) Critical Analysis of Cyberslacking in Organizational Structures. Journal of Human Resource and Sustainability Studies, 2, 70-90.

Lim, V. K. (2002). The IT way of loafing on the job: Cyberloafing, neutralising and organisational justice. Journal of organisational behavior: the international Journal of Industrial, Occupational and Organisational Psychology and Behavior, 23(5), 675-694. 
Lim, V. K., Teo, T. S. ve Loo, G. L. (2002). How do I loaf here? Let me count the ways. Communications of the ACM, 45(1), 66-70.

Mackey, J. D., McAllister, C. P., Brees, J. R., Huang, L. ve Carson, J. E. (2018). Perceived organisational obstruction: A mediator that addresses source-target misalignment between abusive supervision and OCBs. Journal of Organizational Behavior, 39(10), 1283-1295.

Martinko, M. J., Harvey, P., Brees, J. R. ve Mackey, J. (2013). A review of abusive supervision research. Journal of Organizational Behavior, 34(1), 120-137.

Mashal H. (2017). Uncontrolled workplace breaks and productivity. (Doktora Tezi, Walden University, Minnesota). Erişim Adresi: https://scholarworks.waldenu.edu/dissertations/3309/

Mercado, B.K., Giordano, C. ve Dilchert, S. (2017). A meta-analytic investigation of cyberloafing. Career Development International, 22(5),546-564.

Merydith, S. P., Prout, H. T. ve Blaha, J. (2003). Social desirability and behavior rating scales: An exploratory study with the child behavior checklist/4-18. Psychology in the Schools, 40(2), 225-235.

Miller, A. L. (2012). Investigating social desirability bias in student self-report surveys. Educational Research Quarterly, 36(1), 30-47.

Mitchell, M. S. ve Ambrose, M. L. (2007). Abusive supervision and workplace deviance and the moderating effects of negative reciprocity beliefs. Journal of Applied Psychology, 92(4), 1159.

Moody, G. D. ve Siponen, M. (2013). Using the theory of interpersonal behavior to explain non-workrelated personal use of the Internet at work. Information \& Management, 50(6), 322-335.

Mysammy (2013, 21 May1s). Cyberloafing Infographic: Personal internet use at work infographic. Erişim Adresi: www.mysammy.com/cyberloafing-personal-Internet-use-at-work-infographic

Niaei, M., Peidaei, M. M. ve Nasiripour, A. A. (2014). The relation between staff cyberloafing and organisational commitment in organisation of environmental protection. Kuwait Chapter of Arabian Journal of Business and Management Review, 33(2534), 1-13.

Oravec, J. A. (2002). Constructive approaches to Internet recreation in the workplace. Communications of the ACM, 45(1), 60-63.

Orr, J. M., Sackett, P. R., ve Dubois, C. L. (1991). Outlier detection and treatment in I/O psychology: A survey of researcher beliefs and an empirical illustration. Personnel Psychology, 44(3), 473-486.

Orhunbilge, N. (2000). Uygulamah Regresyon ve Korelasyon Analizi. İstanbul: Avcıl Basım Yayın.

Örücü, E. ve Yıldız, H. (2014). İşyerinde Kişisel İnternet ve Teknoloji Kullanımı: Sanal Kaytarma. Ege Academic Review, 14(1), 99-114.

Özince, E. (2008). Finansal Sektör - Uluslararası Gelişmeler ve Türkiye Deneyimi. Muhasebe ve Finansman Dergisi, 40, 24-44.

Özkalp, E., Aydın, U. ve Tekeli, S. (2012). Sapkın örgütsel davranışlar ve çalışma yaşamında yeni bir olgu: Sanal kaytarma (cyberloafing) ve iş ilişkilerine etkileri. Çimento İşveren Sendikası Dergisi, 26(2), 18-33.

Piotrowski, C. (2012). Cyberloafing: A content analysis of the emerging literature. Journal of Instructional Psychology, 39(3-4), 259-262.

Podsakoff, P. M., MacKenzie, S. B., Lee, J. Y. ve Podsakoff, N. P. (2003). Common method biases in behavioral research: A critical review of the literature and recommended remedies. Journal of Applied Psychology, 88(5), 879.

Rahimnia, F. ve Mazidi, A. R. K. (2015). Functions of control mechanisms in mitigating workplace loafing; evidence from an Islamic society. Computers in Human Behavior, 48, 671-681.

Robinson, S. L. ve Bennett, R. J. (1995). A typology of deviant workplace behaviors: A multidimensional scaling study. Academy of Management journal, 38(2), 555-572.

Raykov, T. ve Marcoulides, G. A. (2008). An introduction to applied multivariate analysis (2.bs.). New York: Routledge.

Saalfield, P. (2005, 19 Temmuz). Internet misuse costs businesses $\$ 178$ billion annually. Erişim Adresi: https://www.infoworld.com/article/2671119/internet-misuse-costs-businesses--178-billionannually.html. 
Saleh, M., Daqqa, I., AbdulRahim, M. B. ve Sakallah, N. (2018). The effect of cyberloafing on employee productivity. International journal of advanced and applied sciences, 5(4), 87-92.

Sao R, Chandak S, Patel B ve Bhadade P. (2020). Cyberloafing: Effects on employee job performance and behaviour. International Journal of Recent Technology and Engineering (IJRTE), 8 (5): ISSN: 22773878 .

Serdar, E., ve Özsoy, E. (2019). İstismarcı yönetim: bir literatür taraması. İzmir Katip Çelebi Üniversitesi İktisadi ve İdari Bilimler Fakültesi Dergisi, 2(1), 1-11.

Sezici, E. ve Güven, Ö. Z. (2017). İstismarcı yönetici algısının kaytarma üzerindeki etkisinde duygusal tükenmenin aracilık rolü: Otel işletmelerinde bir inceleme. Anatolia: Turizm Araştırmalar Dergisi, 28(1), 58-68.

Shaddiq, S., Haryono, S., Muafi, M. ve Isfianadewi, D. (2021). Antecedents and Consequences of Cyberloafing in Service Provider Industries: Industrial Revolution 4.0 and Society 5.0. The Journal of Asian Finance, Economics, and Business, 8(1), 157-167.

Sharma, S. K. ve Gupta, J. N. D. (2004). Improving workers' productivity and reducing internet abuse. Journal of Computer Information Systems, 44 (2), 74-78.

Shiu, E., Pervan, S. J., Bove, L. L. ve Beatty, S. E. (2011). Reflections on discriminant validity: Reexamining the Bove et al. (2009) findings. Journal of Business Research, 64(5), 497-500.

Singer, E. (2004). Confidentiality, risk perception, and survey participation. Chance, 17(3), 30-34.

Skarlicki, D. P. ve Folger, R. (1997). Retaliation in the workplace: The roles of distributive, procedural, and interactional justice. Journal of Applied Psychology, 82(3), 434.

Skarlicki, D. P., Folger, R. ve Gee, J. (2004). When Social Accounts Backfire: The Exacerbating Effects of a Polite Message or an Apology on Reactions to an Unfair Outcome 1. Journal of applied social psychology, 34(2), 322-341.

Tabachnick, B.G. ve Fidell, L.S. (2013). Using Multivariate Statistics (6.bs.). Boston: Allyn ve Bacon.

Tepper, B. J. (2000). Consequences of abusive supervision. Academy of Management Journal, 43(2), 178190.

Tepper, B. J., Duffy, M. K., Henle, C. A. ve Lambert, L. S. (2006). Procedural injustice, victim precipitation, and abusive supervision. Personnel Psychology, 59(1), 101-123.

Tepper, B. J. (2007). Abusive supervision in work organisations: Review, synthesis, and research agenda. Journal of Management, 33(3), 261-289.

Tepper, B. J., Moss, S. E. ve Duffy, M. K. (2011). Predictors of abusive supervision: Supervisor perceptions of deep-level dissimilarity, relationship conflict, and subordinate performance. Academy of Management Journal, 54(2), 279-294.

Thau, S. ve Mitchell, M. S. (2010). Self-gain or self-regulation impairment? Tests of competing explanations of the supervisor abuse and employee deviance relationship through perceptions of distributive justice. Journal of Applied Psychology, 95(6), 1009-1031.

Toprak M.A. (2005, Kasım). Çalı̧̧anların Bakışı Açısından Verimlilik, Temel Değerler, Başarı Faktörleri: Bir Alan Araştırması, V. Ulusal Üretim Araştırmaları Sempozyumu, İstanbul Ticaret Üniversitesi, İstanbul.

Turnley W.H. ve Feldman D.C. (1999). The impact of psychological contract violations on exit, voice, loyalty and neglect. Human Relations, 52 (7), 895-922.

Türkiye Katılım Bankaları Birliği (2020, Ocak). Sektör Bilgileri. Erişim Adresi: https://www.tkbb.org.tr/banka-genel-bilgileri

Türkiye Bankalar Birliği (2020, Ocak). İstatistiki Raporlar. Erişim Adresi: https://www.tbb.org.tr/tr/bankacilik/banka-ve-sektor-bilgileri/istatistiki-raporlar/59

Uğuz, Ş., İnanç, B. Y., Yerlikaya, E. E. ve Aydın, H. (2004). Endicott işte üretkenlik ölçeği'nin (EiÜÖ) Türk toplumunda geçerlilik ve güvenilirliğinin değerlendirilmesi. Türk Psikiyatri Dergisi, 15(3), 209214. 
Ülbeği, İ. D., Özgen, H. M. ve Özgen, H. (2014). Türkiye'de istismarcı yönetim ölçeğinin uyarlaması: Güvenirlik ve geçerlik analizi. Çukurova Üniversitesi Sosyal Bilimler Enstitüsü Dergisi, 23(1), 1-12

Valle, M., Kacmar, K. M., Zivnuska, S. ve Harting, T. (2019). Abusive supervision, leader-member exchange, and moral disengagement: A moderated-mediation model of organisational deviance. The Journal of social psychology, 159(3), 299-312.

Vitak, J., Crouse, J. ve LaRose, R. (2011). Personal internet use at work: Understanding cyberslacking. Computers in Human Behavior, 27(5), 1751-1759.

Wang, W., Mao, J., Wu, W. ve Liu, J. (2012). Abusive supervision and workplace deviance: The mediating role of interactional justice and the moderating role of power distance. Asia Pacific Journal of Human Resources, 50(1), 43-60.

Weissenfeld, K., Abramova, O. ve Krasnova, H. (2019, Şubat). Antecedents for cyberloafing-A literature review., 14th International Conference on Wirtschafts informatik, Almanya.

Yağcl, M. ve Yüceler, A. (2016). Kavramsal boyutlariyla sanal kaytarma. International Journal of Social Sciences and Education Research, 2(2), 531-540.

Yeşilyurt C. (2009) Türkiye'deki iktisat bölümlerinin göreceli performanslarının veri zarflama analizi yöntemiyle ölçülmesi: KPSS 2007 verilerine dayalı bir uygulama, Atatürk Üniversitesi İktisadi ve İdari Bilimler Dergisi, 23(4), 135-147.

Yıldız, H., Yıldız, B. ve Ateş H. (2014). Sanal kaytarma davranışlarının sergilenmesinde örgütsel adalet algısının rolü var mıdır?. Bilgi Ekonomisi ve Yönetimi Dergisi, 10(2).

Yıldız, H., Yıldız, B., ve İyigün, N. Ö. (2016). Psikolojik sözleşme algısının sanal kaytarma davranışları üzerindeki etkisi. Erciyes Üniversitesi İktisadi ve İdari Bilimler Fakültesi Dergisi, 47, 147-165.

Yılmaz, E. ve Koğar, H. (2015). Uç değerle baş etmede kullanılan farklı tekniklerin bazı istatistiksel analiz sonuçları üzerindeki etkisi. Başkent University Journal of Education, 2(1), 61-67.

Zait, A. ve Bertea, P. (2011). Methods for testing discriminant validity. Management \& Marketing Journal, 9(2), 217-224. 